\title{
Review \\ Multiple Targets for Oxysterols in Their Regulation of the Immune System
}

\author{
Lisa Reinmuth ${ }^{1}$, Cheng-Chih Hsiao ${ }^{2,3}$, Jörg Hamann ${ }^{2,3}$ (D), Mette Rosenkilde ${ }^{1, * \mathbb{C}}$ and John Mackrill ${ }^{4, *(\mathbb{D})}$ \\ 1 Laboratory for Molecular Pharmacology, Department of Biomedical Sciences, University of Copenhagen, \\ Blegdamsvej 3B, 2200 Copenhagen, Denmark; lisa.reinmuth@sund.ku.dk \\ 2 Department of Experimental Immunology, Amsterdam Institute for Infection and Immunity, \\ Amsterdam University Medical Centers, Meibergdreef 9, 1105 AZ Amsterdam, The Netherlands; \\ c.hsiao@amsterdamumc.nl (C.-C.H.); j.hamann@amsterdamumc.nl (J.H.) \\ 3 Neuroimmunology Research Group, The Netherlands Institute for Neuroscience, \\ 1105 BA Amsterdam, The Netherlands \\ 4 Department of Physiology, School of Medicine, BioSciences Institute, University College Cork, College Road, \\ T12 YT20 Cork, Ireland \\ * Correspondence: rosenkilde@sund.ku.dk (M.R.); j.mackrill@ucc.ie (J.M.); Tel.: +353-(0)21-490-1400 (J.M.)
}

Citation: Reinmuth, L.; Hsiao, C.-C.; Hamann, J.; Rosenkilde, M.; Mackrill, J. Multiple Targets for Oxysterols in Their Regulation of the Immune System. Cells 2021, 10, 2078. https:// doi.org/10.3390/cells10082078

Academic Editor: Ichiro Maruyama

Received: 1 July 2021

Accepted: 11 August 2021

Published: 13 August 2021

Publisher's Note: MDPI stays neutral with regard to jurisdictional claims in published maps and institutional affiliations.

\begin{abstract}
Oxysterols, or cholesterol oxidation products, are naturally occurring lipids which regulate the physiology of cells, including those of the immune system. In contrast to effects that are mediated through nuclear receptors or by epigenetic mechanism, which take tens of minutes to occur, changes in the activities of cell-surface receptors caused by oxysterols can be extremely rapid, often taking place within subsecond timescales. Such cell-surface receptor effects of oxysterols allow for the regulation of fast cellular processes, such as motility, secretion and endocytosis. These cellular processes play critical roles in both the innate and adaptive immune systems. This review will survey the two broad classes of cell-surface receptors for oxysterols (G-protein coupled receptors (GPCRs) and ion channels), the mechanisms by which cholesterol oxidation products act on them, and their presence and functions in the different cell types of the immune system. Overall, this review will highlight the potential of oxysterols, synthetic derivatives and their receptors for physiological and therapeutic modulation of the immune system.
\end{abstract}

Keywords: oxysterols; ion channels; immune response; pharmacology; structure-function; inflammation; autoimmunity; infectious diseases

\section{Introduction}

Oxysterols are cholesterol oxidation products, which can be absorbed from the diet, or generated by auto-oxidation or by enzymatic mechanisms. Oxysterols result from oxidation of cholesterol on the sterol rings, the side chain, or both [1]. This generates a diverse range of oxysterol congeners that have distinct biophysical properties. In addition to being reaction intermediates in the synthesis of bile-acids and steroid hormones, many oxysterols are biologically active signalling molecules, regulating diverse cellular processes. Consequently, the dysregulation of oxysterol production and action is associated with a range of diseases, including cancers [2], atherosclerosis [3], age-related macular degeneration, neurodegeneration and osteoporosis [1]. The focus of the current review are the roles of oxysterols in immune system physiology and pathology [4-6].

Oxysterols exert their biological effects in a variety of ways, potentially including mechanisms that are yet to be elucidated. Most oxysterols have direct biophysical effects on lipid bilayers, including the modification of cholesterol organization and associated membrane subdomains [7]. Several side-chain oxysterols, including 25-hydroxycholesterol (25-HC, synthesized by cholesterol 25-hydroxylase) and 27-hydroxycholesterol (27-HC, generated by cytochrome $\mathrm{p} 450$ oxidase 27A1, CYP27A1), play roles in the innate immune 
system, blocking the infection and replication of viruses and bacteria. For example, 25-HC hinders the replication of SARS-CoV-2 by inhibiting membrane fusion [8]. It also alters the mechanical properties of lipid membranes, leading to local variations in stiffness, which can influence the entry and egress of pathogens [9]. Ring-modified oxysterols, such as 7ketocholesterol (7-KC), also inhibit viral replication and infection, but exert robust cytotoxic effects on host cells [10]. Oxysterols can indirectly modify membrane properties: 25HC activates acyl-CoA:cholesterol acyltransferase (ACAT) in macrophages, leading to the rapid internalization of an accessible pool of cholesterol, thereby blocking infection by Shigella flexneri or Listeria monocytogenes [11].

Since oxysterols are hydrophobic, they readily diffuse into cells to interact with intracellular receptors. Oxysterol-binding proteins (OSBPs) and OSBP-related proteins (ORPs) are a family of cytosolic receptors for oxysterols. In humans, the OSBP/ORP family is encoded by 12 distinct genes, with all members possessing an OSBP-related ligand-binding domain and the majority having a pleckstrin-homology domain near the N-terminus, that allows for interaction with phosphatidtidylinositol phosphate lipids. It is thought that all OSBPs/ORPs participate in the transfer of sterols and other small molecules at sites of membrane contact between different organelles [12], but additional roles have also been identified, some of which are specific to particular members $[13,14]$. Several of these roles were first identified in cells derived from the immune system. Inositol 1,4,5-trisphosphate $\left(\mathrm{IP}_{3}\right)$ is generated upon the activation of $\mathrm{G}$ protein-coupled receptors (GPCRs) or receptor tyrosine kinases, through the action of phospholipase C (PLC) isozymes on the lipid phosphatidylinositol-4,5-bisphosphate $\left(\mathrm{PIP}_{2}\right) . \mathrm{IP}_{3}$ is a second messenger that releases $\mathrm{Ca}^{2+}$ from intracellular stores, such as the endoplasmic reticulum (ER), via $\mathrm{IP}_{3}$ receptor $\left(\mathrm{IP}_{3} \mathrm{R}\right)$ channels. Oxysterols exert congener- and cell-type-selective effects on cytoplasmic $\mathrm{Ca}^{2+} \mathrm{lev}^{-}$ els [15]. In T cell acute lymphoblastic leukemia cells, ORP4L assembles the receptor CD3 $\varepsilon$, its transducers $\mathrm{G} \alpha_{\mathrm{q} / 11}$ and the effector PLC- $\beta 3$ into a signalling complex, generating $\mathrm{IP}_{3}$, which triggers $\mathrm{Ca}^{2+}$ release via $\mathrm{IP}_{3}$ Rs. This increases mitochondrial matrix $\mathrm{Ca}^{2+}$, thereby activating oxidative respiration [16]. In the Jurkat T-lymphoma cell line, ORP4L interacts directly with $\mathrm{IP}_{3} \mathrm{Rs}$, enhancing $\mathrm{IP}_{3}$-induced $\mathrm{Ca}^{2+}$ release [17]. In mouse bone marrow-derived mast cells, ORP9S is phosphorylated by a type 2 phosphoinositide-dependent protein kinase (PKD-2, most likely a protein kinase $C-\beta(P K C-\beta))$ and inhibits phosphorylation of Akt/protein kinase B at S473 [18]. OSBPs/ORPs play roles in viral infection and replication. For example, the drug itraconazole inhibits the replication of a diverse range of viruses, including hepatitis $C$ and poliovirus, via the antagonism of the lipid transfer activities of OSBP and of ORP4 [19].

A key class of intracellular receptors for oxysterols exert their cellular effects through changes in the transcription of target genes [20]. Archetypal nuclear receptors for oxysterols are the liver $X$ receptors (LXRs), which exist as heterodimers with retinoid $X$ receptors (RXRs). Of the two human LXRs, LXR $\alpha$ (nuclear receptor subfamily 1 , group $\mathrm{H}$, member 3 (NR1H3)) is abundant in macrophages, liver, intestine, adipose tissue, lung, kidney and adrenal gland, whereas LXR $\beta$ (NR1H2) is ubiquitous [21]. Binding of certain sidechain oxysterols (22(R)-HC, 24(S)-HC, 25-HC, or 27-HC) elicits conformational changes that promote dissociation of LXR-RXR complexes from transcriptional co-repressors, and stimulates LXR-RXR interaction with the sterol response elements (SREs) of target genes. These mechanisms increase the transcription of genes involved in cholesterol clearance (ATP-binding cassette A1 and G1, CYP7A1, apolipoprotein E) and those which regulate multiple components of the immune system [4].

There are three widely expressed members of the SRE-binding protein family (SREBP1a, SREBP1b and SREBP2), which are transcription factors tethered to the ER via a transmembranespanning domain. In the ER, SREBPs interact with SREBP cleavage-activating proteins (SCAPs). When the levels of cholesterol and oxysterols are low, SCAP transports SREBPs to the Golgi apparatus where it is cleaved by two resident proteases, releasing an N-terminal domain. This domain translocates to the nucleus, where it binds to SREs in the promoters of target genes [22]. These target genes include those involved in fatty acid metabolism, 
cholesterol transport and immune responses [6]. Cholesterol, or certain oxysterols (most notably 25-HC), bind to the ER-resident proteins insulin-induced gene-1 (INSIG-1) or INSIG-2, promoting interaction with SCAP [23], preventing its translocation to the Golgi and activation of SREBP. Consequently, cholesterol and some oxysterols are negative modulators of SREBP-dependent transcription.

The RXR-related orphan receptor (ROR) family members $\alpha$ and $\gamma$ can bind to certain oxysterols, particularly 7-position substituted congeners, with high affinity. This activates the transcription of target genes, including those involved in immunity. Other oxysterols, such as 24S-hydroxycholesterol (24S-HC) and 24S,25-epoxycholesterol, suppress the activities of these transcription factors [24].

Several oxysterols are selective estrogen receptor modulators. For example, 27-HC binds to both the $\alpha$ - and $\beta$-estrogen receptors, inducing transcription of their target genes [25]. In contrast, 27-HC antagonises the protective effects of estrogen against atherosclerosis in a diet-induced mouse model of hypercholesterolaemia [26].

Certain oxysterols influence the transcription of target genes via epigenetic mechanisms. During investigations of the effects of high extracellular glucose on the regulation of genes involved in non-alcoholic fatty liver disease, it was discovered that elevated 25-HC promoted methylation of $\mathrm{CpG}$ islands, acting as a direct, endogenous agonist of DNA methyltransferase 1 (DNMT1) [27]. Genes whose transcription is regulated in this manner include voltage-gated $\mathrm{Ca}^{2+}$ channel subunits, $\mathrm{Ca}^{2+}$-calmodulin kinases, those involved in lipid metabolism, inflammation and MAPK signalling. Within the immune system, cholesterol 25-hydroxylase, the enzyme that produces $25-\mathrm{HC}$, is particularly abundant in macrophages, and this oxysterol suppresses IgA synthesis [28]. In addition, 25-HC can be sulfated at its 3-position by sulfotransferase 2B1b to generate 25-HC3S, which can be further sulfated by sulfotransferase 2A1 [29]. In contrast to 25-HC, 25-HC3S is a potent antagonist of DMNT-1, $-3 a$ and $-3 b$, and opposes its actions on target genes [27,30,31]. In a lipopolysaccharide-induced model of acute lung injury, 25-OHC concentrations are elevated, potentially promoting inflammation and the recruitment of leukocytes [32]. Since 25-HC3S has beneficial effects in models of non-alcoholic fatty liver disease, organ damage and inflammation, and has been evaluated favourably in clinical trials, further elucidation of the roles of this oxysterol metabolite in the regulation of immune cells will be of great value [31].

In addition to the direct effects of oxysterols on nuclear receptors, there is also considerable cross talk between signalling pathways modulated by cholesterol oxidation products and those regulated by other bioactive sterols. Some of these sterols are important modulators of the immune system. For example, active vitamin D (1,25-dihydroxycholesterol) inhibits the expression of CYP7A (cholesterol 7 hydroxlase $\alpha$ ) by promoting the formation of a complex between the vitamin D receptor and LXR $\alpha$ [33]. The enzyme 11 $\beta$-hydroxysteroid dehydrogenase type 1 (11 $\beta$-HSD1) can convert $7-\mathrm{KC}$ to $7 \beta$-hydroxycholesterol $(7 \beta-\mathrm{HC})$, and also interconverts active cortisol (a glucocorticoid hormone) into inactive cortisone. In adipocytes, co-incubation with 7-KC repressed, and $7 \beta-\mathrm{HC}$ enhanced, the biological effects of cortisol through a mechanism that involved changing the direction of substrate flux through the 11 $\beta$-HSD1 and 11 $\beta$-HSD2 enzyme pair [34].

Despite the potential for therapeutic exploitation of nuclear receptor-mediated oxysterol signalling in the regulation of immune cell biology, this does have two key limitations. Firstly, transcriptional mechanisms are slow, with a lag of tens of minutes to hours between the initial stimulus (change in the levels of a particular oxysterol) and the cellular response. This may be unsuitable for the control of cellular processes that can occur over much shorter timescales, such as motility, endocytosis and secretion. Secondly, in terms of the development of oxysterol-based immunomodulatory drugs, LXR agonists act on the liver to increase the expression of SREBP1c, which promotes the clinically unfavourable condition of hypertriglyceridemia $[6,35,36]$. Targeting the main focus of the current review, cell-surface receptors for oxysterols might provide effective solutions to these limitations. These targets can be divided into two classes: G protein-coupled receptors (GPRs) and ion 
channels. Evidence for the presence of these proteins in different immune cells was derived from two key sources: analyses of four independent transcriptomic databases from human immune cells (Supplemental Figure S1) [37-39] and a review of the scientific literature (Supplemental Figure S2).

\section{G Protein-Coupled Receptors}

G protein-coupled receptors (GPCRs) are predominantly located in the cell-surface membrane. They have a characteristic 7-transmembrane (7TM) topology and regulate the activities of second-messenger-producing enzymes. Figure 1 summarizes some of the properties of the three types of GPCR that are present in the mammalian immune system and which interact with oxysterols. Although there are four types of GPCR that are known to be modulated by oxysterols, one of these, GPR17, is undetectable in the immune cell types that we investigated, see Supplemental Figure S1. Figure 2 provides an overview of the distribution of these receptors among cells of the immune system.

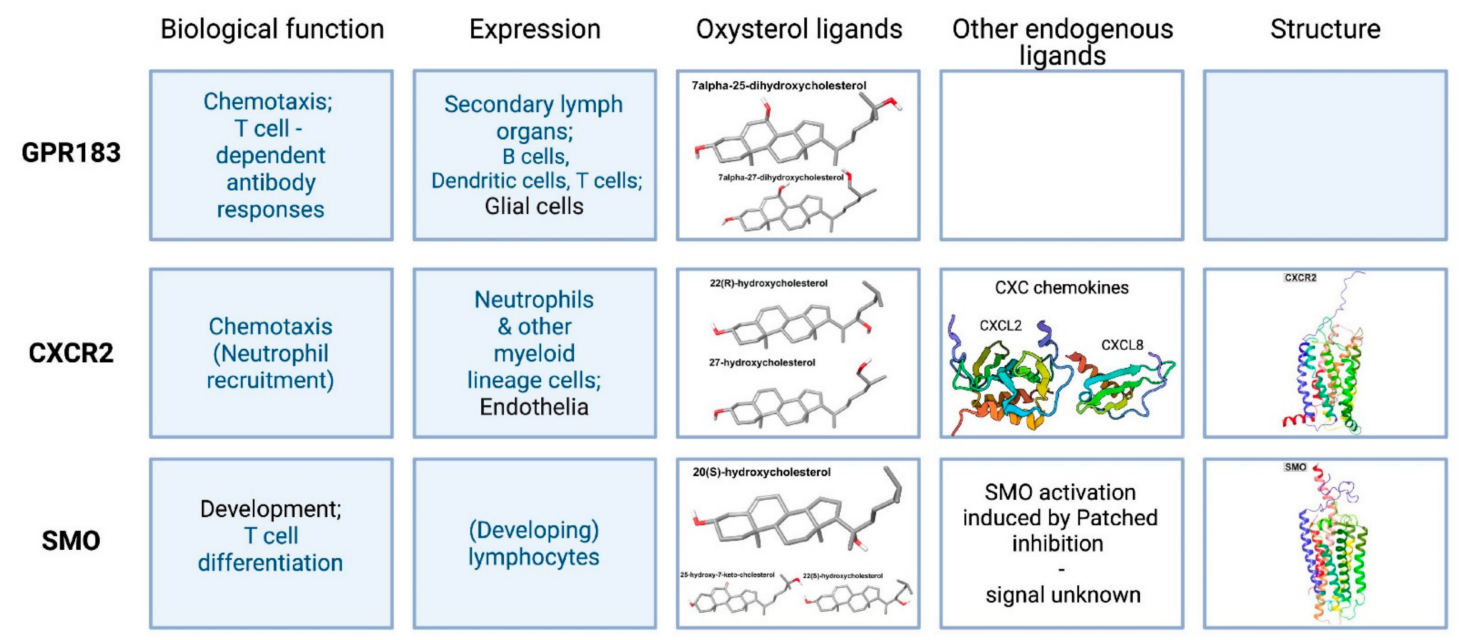

Figure 1. Overview of the biological functions and distribution (Expression)s of oxysterol activated GPCRs in cells of the immune system. The structures of their endogenous oxysterol ligands, details of other endogenous ligands and, where available, models of their three-dimensional structures of these receptors are also shown. This image was created using BioRender (BioRender.com).

\subsection{Epstein-Barr Virus-Induced Receptor 2, or GPR183}

2.1.1. Cellular Expression Pattern and Overall Biological Function

Epstein-Barr virus-induced receptor 2 (EBI2), or GPR183, is mainly expressed by immune cells and related tissues. Secondary lymph organs have an especially abundant expression, but the lungs and the gastrointestinal tract also show comparably high expression levels [40].

The best-established role for the receptor lies in the positioning of cells in secondary lymph organs, and especially the facilitation of $\mathrm{T}$ cell-dependent antibody responses. Through the interplay and differential expression of enzymes in the secondary lymphoid organs, a gradient of $7 \alpha, 25-\mathrm{OHC}$ is created, with the highest concentration at the $\mathrm{B} / \mathrm{T}$ cell border and the outer follicular regions [41]. B cells undergo the sequential up and down regulation of GPR183, in parallel with the expression of several other chemotactic GPCRs. Activation of B cells by B-cell receptor (BCR) binding leads to an upregulation of GPR183. This, in turn, results in the lymphocyte alignment on the T-cell border, a high ligand concentration region, by integrated signalling via both GPR183 and C-C chemokine receptor 7 (CCR7) [42,43]. Here, they can receive secondary differentiation signals from T-helper (Th) cells. If they are T cell-stimulated, GPR183 expression is downregulated, which allows the B cells to move to the germinal centres in the B-cell zone for antibody refinement or escape to the circulation. Expression in the germinal centre is generally 
lowered, but the differential expression of GPR183 still correlates with localization in the light or dark zone $[43,44]$. Memory B cells, on the other hand, stay on the fringes of the follicular area, due to high GPR183, normal CCR7 levels and downregulated CCR5 expression. By a similar mechanism, corresponding specialized TH cells are localized to the same region [45].

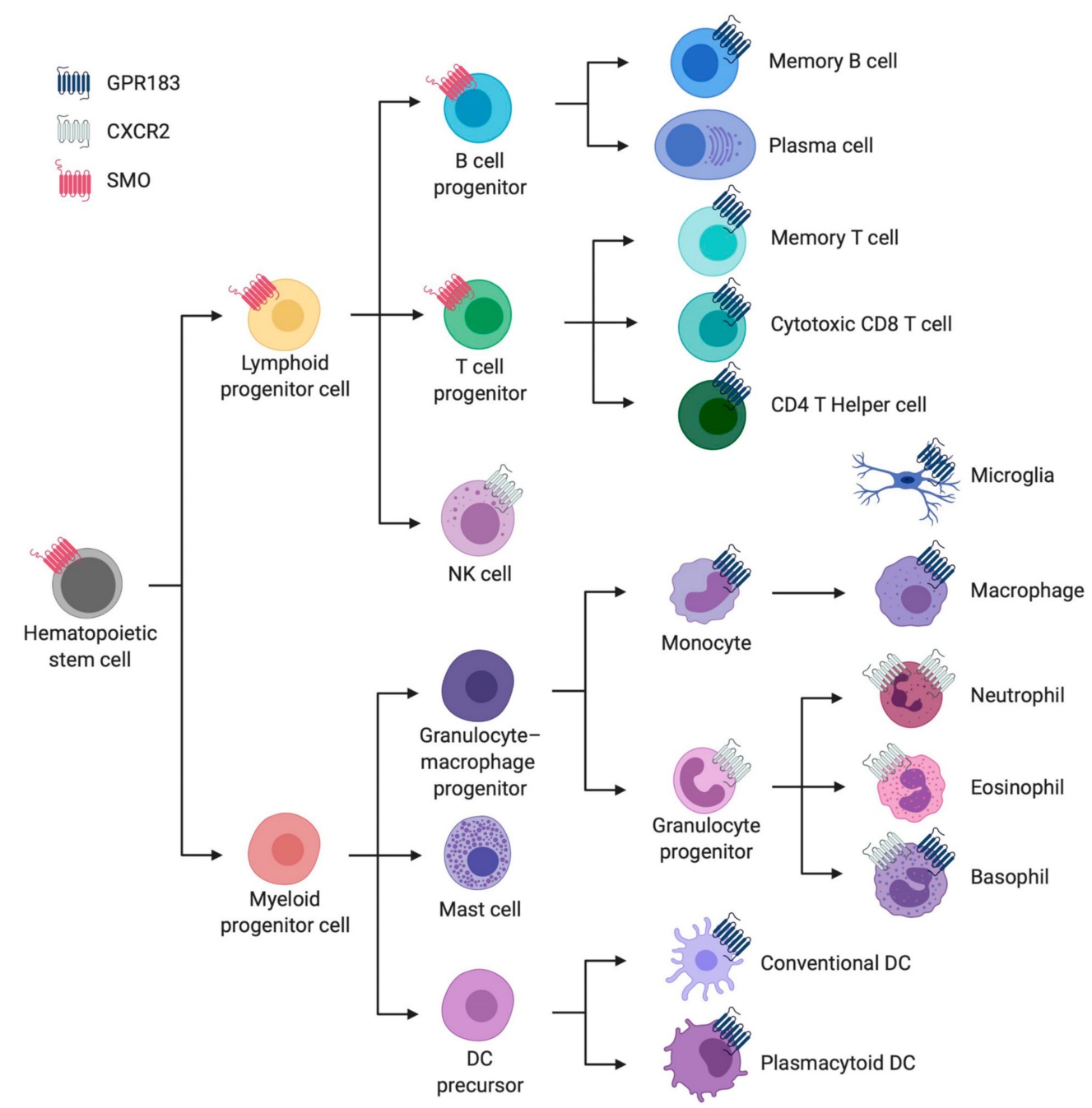

Figure 2. Overview of the main immune cell types from the hematopoietic lineage with an abstraction of their cellular expression of the three GPCRs discussed in this article. These GPCRs are represented by three distinct colours: purple for GPR183, light grey for CXCR2 and red for $S M O$. This overview was created in BioRender (BioRender.com) and is based on a consensus from four independent transcriptomic data sets from human immune cells [37-39], as summarized in Supplemental Figure S1.

$\mathrm{T}$ cells also receive cues from oxysterols via GPR183. In their development process, GPR183 influences central tolerance, especially in CD4 single positive (SP) cells. It regulates $\mathrm{CD}^{+}$effector and regulator cell generation by increasing encounters with antigenpresenting cells, such as dendritic cells (DCs), and thus increases the number of encounters with different, rare self-antigens [46]. GPR183 remains highly expressed on CD4 ${ }^{+} \mathrm{T}$ cells compared to $\mathrm{CD} 8^{+} \mathrm{T}$ cells and also enhances $\mathrm{CD} 4-\mathrm{DC}$ encounters in secondary lymph organs. Thus, it enables the early differentiation of $\mathrm{CD} 4^{+}$helper cells [47], which in turn facilitates more efficient $\mathrm{CD} 8^{+} \mathrm{T}$ - and B-cell responses. In exemplum, GPR183 stimulates $\mathrm{T}$ follicular helper cell ( $\mathrm{TfH}$ ) differentiation and then induces secondary migration to the follicles [48]. 
Bringing it back full circle, DCs also express GPR183, and react to oxysterol cues by migration. This has mainly been studied in context of correct positioning in the spleen, in the bridging channels unto activation [49]. In activated DCs GPR183 is also responsible for localization at the outer $\mathrm{T}$ zone, where they determine $\mathrm{TH}$ cell differentiation to $\mathrm{TfH}$ cells [50]. GPR183 expression has also been found relevant in plasmacytoid (pDC) and myeloid (mDC) subsets, where it downregulates interferon responses upon Toll-like receptor (TLR) binding, as well as migration towards the spleen [51]. These regulatory effects are also supported by an observed interplay between tuberculosis infection and type two diabetes, where reduced GPR183 expression correlated with increased interferon levels and infection severity [21].

The expression of GPR183 in eosinophils, together with increased oxysterol production in inflamed airways, could be responsible for recruitment to the tissue [52]. Another specialized immune compartment is the gastrointestinal tract, where lymphoid tissue inducer (LTi)-like group 3 innate lymphoid cells (ILC3) have been found to be organized in a GPR183 dependent manner and this affects inflammatory processes in the bowel $[53,54]$.

GPR183 is also expressed on astrocytes and microglia in the brain, where it may thus effect neuroinflammatory diseases [55-58]. In the context of neuropathic pain, GPR183expressing astrocytes and microglia accumulate in the spinal cord and allodynic effects can be attenuated by the inhibition of this receptor in vivo [59].

Related to this, several studies have looked at the effects of the GPR183-oxysterol axis in multiple sclerosis. GPR183 dependent T-lymphocyte trafficking seems to be of significant relevance here. In particular, $\mathrm{T}_{\mathrm{H}} 17$ and memory lymphocytes were attracted by high $7 \alpha, 25-\mathrm{OHC}$ concentrations, which can be established by activated microglia in inflammatory lesions [60-62].

Unrelated to the immune system, GPR183 is also expressed on monocyte/osteoclasts precursors, and thus heightened $7 \alpha, 25-\mathrm{OHC}$ secretion by osteoblasts, and in an autocrine manner by osteoclast precursors themselves, provides signals for bone resorption [63]. This might also be of relevance in the control of bone mineral density during systemic inflammatory or high cholesterol settings.

\subsubsection{The Chemistry and Production of Endogenous Oxysterols That Bind GPR183}

$7 \alpha, 25-\mathrm{OHC}$ has been determined to be the endogenous ligand with the highest affinity and strongest activity for GPR183, though other oxysterols like $7 \alpha, 27-\mathrm{OHC}$ or $7 \beta, 25 \mathrm{OHC}$ also activate this receptor, albeit with lower potency and efficacy [64]. $7 \alpha, 25-\mathrm{OHC}$ is synthesized from cholesterol in two steps. The first additional hydroxyl group is added in position 25 facilitated by cholesterol-25 hydroxylase $(\mathrm{CH} 25 \mathrm{H})$; the second is catalysed by CYP7B1 [65]. Alternatively, $7 \alpha, 25-\mathrm{OHC}$ can be produced by a combination of CYP7A1 and CYP3A4 [66,67]. However, this is insufficient to launch normal $\mathrm{T}$ cell-dependent antibody responses [64].

The gradient in the lymph nodes stems mainly from stromal cells. Here, the cellspecific knockout of these key enzymes disrupted B-cell positioning. Several hematopoietic cell types, for example, follicular DCs, have also been shown to express Ch25H and Cyp7b1, but ligand expression in the lymph tissue was not affected by the lack of these enzymes in bone marrow-derived cells [41]. This becomes relevant in normal tissue immune responses, as the key enzymes can be differentially regulated. Innate immune cells, such as DCs and macrophages, increase $\mathrm{Ch} 25 \mathrm{H}$ expression via multiple immune pathways [68]. Lipopolysaccharide (LPS) challenge of mouse macrophages, mimicking bacterial infection, resulted in heightened $\mathrm{Ch} 25 \mathrm{H}$ expression and, correspondingly, increased the plasma concentration of 25-HC in human test subjects [69]. Human primary monocytes express both receptor and ligand producing enzymes, with a marked upregulation upon LPS stimulation [70]. The lungs are suggested to be a tissue where this holds central significance, as $\mathrm{CH} 25 \mathrm{H}$ is especially highly expressed and LPS challenge in $\mathrm{KO}$ mice results in prolonged neutrophilia [71]. Epithelial cells in the airways also upregulate these oxysterolproducing enzymes in chronic obstructive pulmonary disease conditions. Here, the higher 
concentration was shown to attract B cells via GPR183 (and stimulate local lymphoid tissue formation) [72]. An older study also found a correlation between increased 25-HC secretion and decreased IgA class switching, with the same effect in CYP7B1 KO mice [28]. Under normal physiological conditions, 25-HC and 27-HC concentrations are increased in Cyp7b1 $\mathrm{KO}$ mice but, otherwise, the phenotype remains mostly normal. Enzyme function in bile acid synthesis seems to be substitutable [73].

CYP7B1 expression is regulated by nuclear factor kappa B (NF- $\mathrm{kB}$ ) and the Janus kinase signalling pathway, tying it to inflammatory and metabolic stress contexts. In rheumatoid arthritis, for example, upregulation of tumour necrosis factor alpha (TNF $\alpha)$, interleukin 1 (IL-1) and IL-17 induces heightened CYP7B1 expression by fibroblastic cells [74]. During acute lung inflammation Cyp7b1 is also upregulated [75]. In insulin resistance states, on the other hand, CYP7B1 expression is low, while GPR183 and $\mathrm{CH} 25 \mathrm{H}$ are upregulated, leading to accumulation of intermediate oxysterols in non-alcoholic fatty liver disease [76,77]. However, a direct correlation between disease progression and GPR183 signalling was not found. Breast cancer cells downregulate CYP7B1 expression by methylation, and promote CYP27A1 expression by specifically differentiating and recruiting M2 macrophages, leading to a feedback loop increasing $27-\mathrm{HC}$ concentrations. This promotes tumour growth and metastasis [78].

Hydroxysterol dehydrogenase-3 B7 (HSD3B7) is an enzyme relevant in the degradation of $7 \alpha, 25-\mathrm{OHC}$ and a number of other oxysterols to form bile acids. HSD3B7 is expressed in secondary lymph organ stromal cells and fDC and is necessary to create a balanced gradient [41]. It has also been found in the intestines, especially in stromal cells surrounding the lymphoid structures [53]. Interestingly, the cue for fDC localization itself is given by $7 \alpha, 27-\mathrm{OHC}$, which is produced by another enzyme, Cyp27a1, also expressed in stromal cells, but also degraded by HSD3B7 [50]. This might be another mechanism to achieve differential signalling.

Overall, these possible relation certainly shows there is room to explore unravelling the signalling pathways governing the immune system and, in particular, the antibody production capabilities.

\subsubsection{GPR183 Receptor Structure}

To date, there is no resolved receptor structure. However, several attempts at homology modelling have been made, accompanied by extensive mutagenesis studies. Developments in this structure guided approach, with the goal of advancement towards targeted drug discovery, were mainly made by two groups: those of Changlu Liu and of Mette Rosenkilde. Confirmation of a specific binding mode of either the endogenous ligands or existing small molecules remains elusive.

Mutagenesis efforts concentrated on residues in the orthosteric, major and minor binding pocket area, where several amino acids showed effects on signal transduction to G $\alpha$ i or $\beta$-arrestin. Since GPR183 had been described as an orphan receptor until around 2010, several mutagenesis studies were performed, where either the inhibition of supposed constitutive activity occurred, or where binding of the first synthetic compound were analyzed $[79,80]$. By these means, an initial set of functionally important residues was identified. The strongest effects of mutants were seen in R87, increasing activity, and F257 of the CFxP-motif, decreasing it. Several partially conserved chemokine receptor (CXCR) motifs were also detected, in conformity with GPR183 now generally believed to be closely related to that receptor family. Both groups proposed binding poses on homology models based on the phylogenically closest known resolved structure of CXCR4 (PDB:3ODU) or a CXCR4 chimera, but those differ [81]. In the model from Zhang et al., the key interacting residues were proposed to be R87, N114 and E183 [81], of which N114 was later proven to belong to an allosteric metal ion site. However, the groups did agree on the relevance of four residues: R87, Y112, Y116, Y260, which were determined as the key binding residues in the model from Benned-Jensen et al. [82]. A third homology model based on CXCR4 exists, made to compare the orthosteric sites of the three class A GPCRs characterized to 
be oxysterol binding [83]. The one residue not appearing in their binding site prognosis is Y116, since it is rotated in a different direction in the template structure. The modelling of GPR183 on more recent crystal structures includes the PAR1 receptor, where possibilities for biased agonism were in focus. In this process, the receptor has been shown to contain the conserved allosteric sodium binding site found in several class A receptors, with special importance of the main residues D77, N114 and D304 [84].

Further analysis to confirm the specific binding residues is in the making though, to improve identification opportunities for pharmacologically relevant new drug candidates. These days, there are several endogenous oxysterols and small molecule modulators, but a definite site for neither is known. Recent discoveries include a number of allosteric sites in class A GPCRs formerly unconsidered $[85,86]$. Of special interest are binding sites outside of the helices, in the lipid bilayer, since oxysterols, with their highly lipophilic character, would have easy access here. This is also supported by cholesterol molecules, which favour specific sites in resolved structures or even enter receptors from here [87].

\subsection{Chemokine Receptor 2 (CXCR2)}

\subsubsection{Cellular Expression Pattern and Overall Biological Function}

CXCR2 is a chemokine receptor. It is phylogenetically related to CXCR1, with which it shares high sequence similarity and has some overlapping ligands and mechanisms. CXCR2 is highly expressed by innate immune cells and endothelia. One of the main functions is neutrophil recruitment and activation, leading to the creation of a pro-inflammatory environment to promote pathogen clearance. In cancer, neutrophils recruited by this mechanism can also further promote tumour growth and metastasis by the induction of neoangiogenesis and inhibition of cytotoxic T cells [88,89]. Opposing effects have also been demonstrated. Angiogenic effects might also be attributed to CXCR2 expression on endothelial cells, which also leads to chemotaxis in these cells [90].

Several other diseases have been associated with CXCR2 signalling, mostly related to neutrophil activity. Among these are neurodegenerative diseases, such as multiple sclerosis, where increased ROS production leads to sustained neuronal damage [91] and neutrophil activation facilitates blood-brain barrier breakdown [92]. Several other inflammatory diseases are influenced by CXCR2 dysregulated neutrophils. Pancreatitis can be attenuated by the inhibition of CXCR2 signalling on neutrophils, where the main effects are attributed to decreased neutrophil chemotaxis-reducing activation of monocytes and, thus, cell death in the pancreatic tissue [93]. The same holds true in ulcerative colitis, where attenuated chemotaxis leads to a decrease in inflammatory cytokine expression [94,95].

CXCR2 is also expressed in hematopoietic stem cells, where signalling plays a role in homeostasis [96]. It also acts as a mobilization signal for neutrophil release from the bone marrow [97]. Furthermore, the fate of differentiating cells of the myeloid line is dependent on the receptor and a bias towards suppressor cells exists in ligand rich tumour settings [98].

\subsubsection{The Chemistry and Production of Endogenous CXCR2 Ligands}

CXCR2 has several endogenous ligands. The receptor is sensitive to all ELR ${ }^{+}$CXC chemokines to varying degrees [99]. Different sets of these are expressed in different settings, but CXCR2 is recognized as their main receptor. CXCL1 and 2, for example, provide the cue for mobilization of neutrophils from the bone marrow [97] and are contributing factors in CNS autoimmune diseases due to increased immune cell infiltration upon TH17 induced chemokine upregulation [92]. CXCL8, on the other hand, plays a significant role in recruitment to sites of infection and vascular escape [100]. Here, it has been shown that concentration, steepness of the gradient, as well as ligand conformation and complexation, play differential roles in signalling outcomes.

Interestingly, in non-inflammatory, non-disease settings a key regulator of endothelial $\mathrm{ELR}^{+}$CXCL expression seems to be low shear stress as seen in capillaries Shaik et al. [101]. 
This is regulated via $\mathrm{p} 38$, NF- $\mathrm{kB}$ signalling pathway, which relates well to increased expression in inflammatory settings.

Oxysterols are another wide group of endogenous ligands for CXCR2. A broad range of single hydroxylated cholesterol derivates proved to be able to induce migration in neutrophils $[102,103]$. The focus in this study was on 22-HC, due to its higher concentration in tumours. The group reported higher neutrophil recruitment of CXCR2-expressing cells, accompanied by the described pro-tumour effects. They did not, however, see synergistic effects between oxysterols and endogenous CXCLs. The effects seem to be independent from each other, with oxysterols sufficient to induce chemotaxis. A later study also elucidated the effects of 27-HC [89], the second highly abundant oxysterol in cancer. In comparison, they observed increased metastasis with $27-\mathrm{HC}$ treatment. This effect was facilitated by $\gamma / \delta$ T cells, next to the intrinsically important neutrophils, through a vicious cycle between these populations.

\subsubsection{CXCR2 Structure}

Since antagonism of CXCR2 has been suggested as a therapeutic tool in a wide spectrum of issues for several decades, a lot of effort was put into finding, refining and proving the concepts behind a wide panel of compound classes. Methods range from early chimeric proteins and site-directed mutagenesis to partial structure resolution. Finally, in 2019, a full receptor structure, including an endogenous ligand and G protein and a version with a small molecule, were resolved (PDB:6LFL/M/O) [104].

Mutagenesis studies revealed several distinct areas that are responsible for the binding of different ligands. Endogenous CXCLs are thought to bind on the extracellular side, with an emphasis on N-terminal involvement for CXCL1 and probably other ELR ${ }^{+}$CXC chemokines not inducing signalling on CXCR1, and increased importance of ECL2 for binding of CXCL8 [105].

Known CXCR2 antagonists can be divided into several classes, which seem to, at least in part, bind distinct sites on the receptor. Two main sites have been described, one intracellular, possibly interfering with $G$ protein binding, and one inside the transmembrane helical bundle, probably interfering with activation-related conformational changes [106-108]. This intrahelical pocket is located inside of TM 3, 5 and 6, with an entry point from the TM5/6 interface. Interestingly, the environment of the entry channel seems conductive for lipid binding, as seen in the CXCR4 crystal structure, which one might speculate to be a possible site for interaction with oxysterols too.

The intracellular C-terminus of CXCR2 carries a PDZ binding motif, which is relevant for signal transduction via $\mathrm{Na}^{+} / \mathrm{H}^{+}$exchanger regulatory factor (NHERF1), which is especially relevant in neutrophil chemotaxis. Interference with this interaction has also been proven to modulate disease mechanisms $[109,110]$.

The full length cryo-EM receptor structures resolved by Liu et al., 2020 [102] further elucidated the binding of CXCL8, $\mathrm{G}_{\mathrm{i}}$ and an antagonist at the intracellular site, overlapping with the G-protein site. CXCL8 turned out to have a fairly shallow binding compared to other chemokine receptor/ligand complexes. In comparison with CXCR1, two major interaction sites are likely key to permissive $\mathrm{ELR}^{+}$CXCL recognition, the PP-PC motif region on the $\mathrm{N}$ terminus and CSR2 that directly interacts with the ELR motif. Another interesting finding was a resolved cholesterol located on the TM 2, 3, 4 interface at the height of the inner membrane leaflet in the active state structure. This might indicate a different oxysterol binding site, stabilizing the receptor in the active conformation. There have been studies looking at possible effects of cholesterol in general chemokine receptor function [111], and some of the mechanisms might be correlated or overlapping.

\subsection{Smoothened (SMO)}

\subsubsection{Cellular Expression Pattern and Overall Biological Function}

Smoothened $(S M O)$ is a class F GPCR best known for its actions in development and cancer. It is an oncoprotein and part of the hedgehog $(\mathrm{Hh})$ signalling pathway, where it 
is responsible for transmembrane signal transduction. This happens when Hh binding to its receptor Patched relieves inhibition of SMO. Several direct ligands and modulators for SMO have been known for a while $[112,113]$. These can activate or inhibit different steps in the activation cascade, before relocalisation to the basal cilia, or at the stage of final activation [114]. Signalling results in Gli family transcription factor cleavage, where pathway activation leads to activator fragments, while downregulation increases the repressor fragment availability. There are three different mammalian hedgehog proteins, and three Gli factors.

Hh signalling also acts as a regulator in the immune system, Figure 3, and has direct regulatory influences on the adaptive side. Lymphocyte development and fate can be dependent on the Hh pathway and thus on SMO, Figure 3. Differential Hh signalling has been shown to be important in various steps of $\mathrm{T}$ cell differentiation, as well as effector function. In the development sonic hedgehog (SHh)-dependent Gli activation is important for transition of DN1 to DN2 and survival of DN4 cells. Intermediate concentrations accelerate transition to DP cells, while very high or very low concentrations lead to arrest $[115,116]$. In contrast, DN3 survival and later proliferation of DP to SP effector cells increased upon downregulation of Hh pathway activation $[117,118]$.

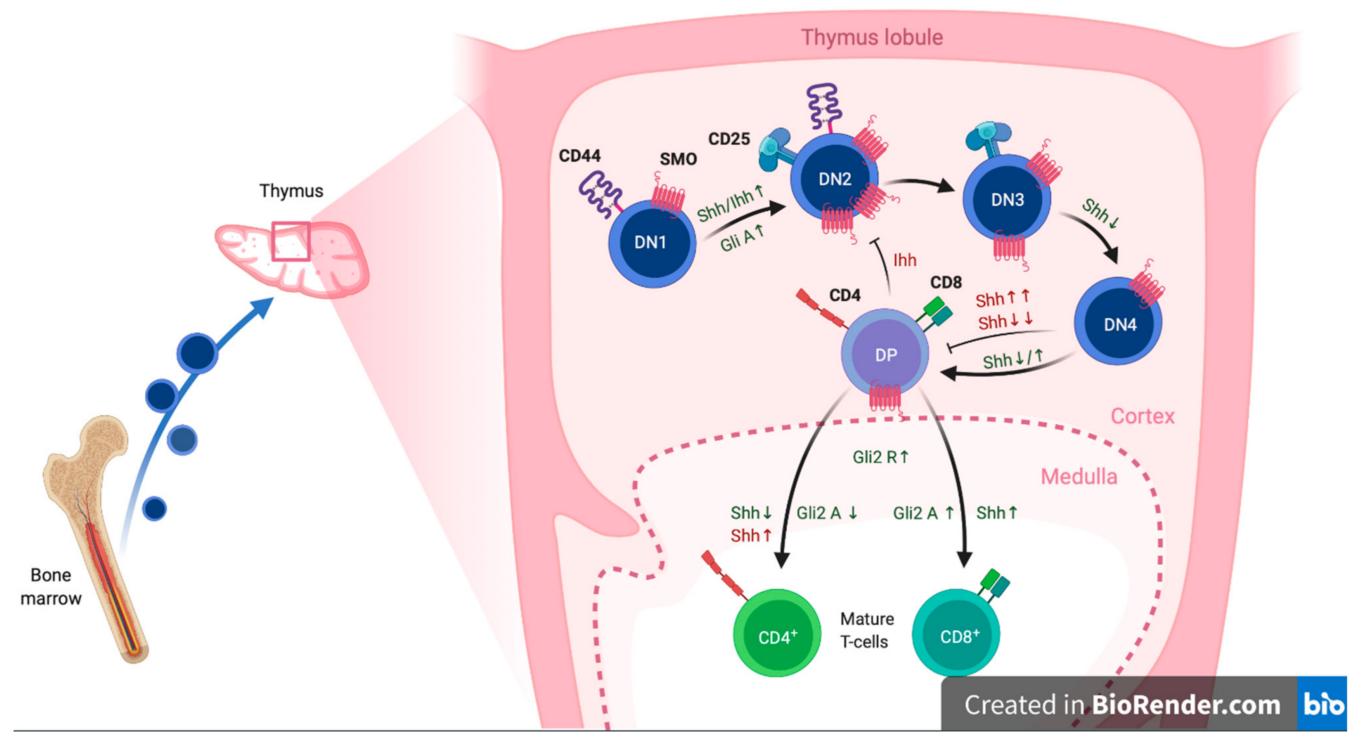

Figure 3. Summary of the differential expression and signalling effects of SMO, including its upstream signals (Hh) and its downstream transcription factors (Gli) on T-cell development in the thymus. Inhibitory signals and effects are highlighted in red, differentiation stimulating effects are marked green. This figure was adapted from "T-Cell Development in Thymus 2", by BioRender.com (2021), retrieved from https://app.biorender.com/biorender-templates.

Shh levels also influence cell fate. Homeostasis and maturation of $\gamma / \delta$ T cells in adult mice are reduced upon inhibition of Hh signalling $[119,120]$. Low SHh increases the rate of differentiation to single positive cells, while skewing balance between $\mathrm{CD} 4^{+}$ and $\mathrm{CD}^{+}$towards $\mathrm{CD}^{+} \mathrm{T}$ cells [120]. $\mathrm{CD}^{+}$cells are themselves skewed towards $\mathrm{Th} 2$ differentiation upon higher signalling via Gli2A [121]. Indian hedgehog (IHh), another $\mathrm{Hh}$ ligand, is needed for efficient $\mathrm{CD} 8^{+}$cytotoxicity [122]. Natural killer T (NKT) cells, another T-cell subpopulation, also possess an increased cytotoxic profile upon SHh stimulation, which they can produce themselves, thus opening the possibility of entering an autocrine loop [123].

Other cells of the adaptive immune system are also subject to Hh signalling. Early B-cell development is dependent on $\mathrm{SHh}$, such that lower levels stimulate differentiation, while higher levels reduce B cell commitment and maturation. This is regulated via Gli3 repression of SHh expression in the stromal cells $[124,125]$. A similar mechanism, as has 
been shown for thymic epithelial cells [120] and used in skin inflammation experiments to check on the influence of Hh signalling on peripheral immune cells [126].

\subsubsection{Chemistry and Production of Endogenous SMO Ligands}

There is a certain degree of speculation about the endogenous ligand of SMO. Neither the mechanism of how Patched inhibits SMO activity, nor which lipid or small molecule might be endogenously responsible for signal transduction, has been elucidated so far. Sterols have been proven to modulate SMO activation though, and their widespread natural occurrence qualifies them as possible endogenous ligands or synergistic allosteric modulators.

In vitro studies found that oxysterol 20(S)-HC is the most potent agonist, though 22(S)-HC, 7-keto-25-HC and 7-keto-27-HC and others activate the receptor [127]. All of these have the normal cholesterol hydroxyl group in position 3 in common. Several of these are able to synergize with each other, or with some of the other known small molecule ligands. Unmodified cholesterol also binds SMO, and can activate the receptor, as well as synergizing with Hh signals or other ligands. An important relation between SMO activation and cholesterol biosynthesis was established long ago [128], but the question of whether cholesterol itself is the endogenous ligand has been raised multiple times over the years and remains unanswered. Fairly recently, a study showed that covalent cholesterol modification takes place on residue D95 in human SMO (in the extracellular CRD binding site) [129]. It might be that either cholesterol esterification, binding or oxysterol availability are regulated by Patched, or that they provide a second signal, maybe ensuring capability of the cell to support the induced changes in transcription. One way in which oxysterols could be enriched for SMO activation has been described by Raleigh et al. [130]. They found that a number of oxysterols, which can synergistically activate SMO via two sites, are enriched in the cilia membrane, where final SMO activation usually takes place.

\subsubsection{SMO Receptor Structure}

There are several receptor structures for SMO, published dating back to 2013, using methods ranging from NMR to conventional X-ray diffraction, to cryo-electron microscopy. A number of ligands have been resolved, bound to fragments, the full-length receptor, or receptor $G$ protein complexes. Especially relevant for this review are the structures containing cholesterols and derivates.

A cysteine-rich domain (CRD) crystal structure from [131] (PDB:5KZV) shows a binding site for 20(S)-OHC. The authors highlighted the binding mode and allosteric transition induced by binding and discovered key residues that are important for both oxysterol and cholesterol binding, which both induce conformational changes and are able to activate the receptor for/with SHh stimulation. The group hypothesized that cholesterol is the endogenous ligand, due to its physiologically relevant concentration. Further studies found that cholesterol seems to be covalently bound in that site at some point. Residue D95, which had been mutated by the aforementioned group and abolished binding in their assays, showed up with a correspondingly increased molecular weight in MS/MS. However, the mechanism of this modification and its explicit regulatory function remain unclear [129].

Comparing different structures resolved in recent years, some major differences can be seen in the tilt of the CRD region. This might be due to different activation states [132,133]. Deshpande et al. [134] solved a full receptor structure, stabilized in the active state by nanobody binding, with cholesterol bound in a deep pocket inside the 7TM region (PDB:6O3C). This binding produces the activating changes for GPCRs, independent of Hh, especially the marked shift in TM6. The binding pocket opens up with the receptor in a more active-like state; for example, with agonists bound higher up in the receptor, or by stimulation from the CRD site. The known antagonists bind at a site that overlaps partly with this deep cholesterol site, thus inhibiting activation this way as well as stabilizing the inactive state. 
A year later, Qi et al. [135] solved more structures of WT and SMO-Gi complexes with several oxysterols and an agonist, SAG, bound (PDB:6XBM). In this way they discovered more, interconnected binding sites, which seem to allow for transfer through the receptor, from the deep 7TM pocket outwards to the CRD.

\subsection{Gamma-Amino Butyric Acid (GABA) Type B Receptors}

GABA is the main inhibitory neurotransmitter in the vertebrate central nervous system. It exerts biological effects by interacting with ionotropic $\mathrm{GABA}_{\mathrm{A}}$ Rs (see Section 3.1.3),

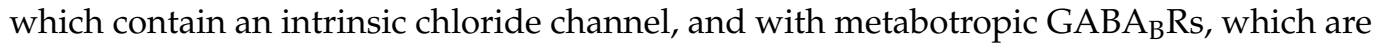
GPCRs. There is limited evidence supporting a modulatory role for oxysterols in $G_{A B A} R$ signalling. In brain slices from the rat lateral septum, the superfusion of 25-HC selectively reduced $\mathrm{GABA}_{\mathrm{B}} \mathrm{R}$ - but not $\mathrm{GABA}_{\mathrm{A}} \mathrm{R}$-dependent inhibitory post-synaptic potentials [136]. Microglia are known to possess both $G A B A_{B} R$ subtypes. The activation of these receptors inhibits microglial IL-6 and IL-12p40 secretion in response to LPS [137]. The GABA ${ }_{B} R-$ selective antagonist, baclofen, is reported to inhibit DC cell activation and their priming of Th17 ${ }^{+} \mathrm{T}$ cells [138].

\section{Ion Channels}

Gating of ion channels permits rapid changes in intracellular ion concentrations in response to diverse stimuli, leading to alterations in membrane potential, the second messenger $\mathrm{Ca}^{2+}$, cell volume, cell-death, gene expression, secretion, endocytosis, or motility. The gating of a limited range of ion channels is known to be modulated by oxysterols, often in a congener- and channel subtype-selective channel fashion. In addition to cell-surface channel proteins, $\mathrm{IP}_{3} \mathrm{RCa}^{2+}$ release channels are located predominantly on the ER and are also modulated by oxysterols. This includes the stimulation of the proteolytic degradation of $\mathrm{IP}_{3} \mathrm{Rs}$ [139], and the assembly of $\mathrm{IP}_{3} \mathrm{R}$ signalling complexes by [16], and direct interactions with, ORP4L [17]. The cell-surface ion channels that are modulated by oxysterols can be divided into three functional categories: those gated by ligands; those gated by changes in membrane potential (voltage-gated); and those gated by multiple stimuli (multi-modal gating). The presence and roles of these channels in the immune system are largely unexplored. Their levels of transcription in immune cells are summarized in Figure 4. These channels have considerable potential as targets for the development of new therapies to combat immune disorders, including autoimmune diseases $[4,5]$.

\subsection{Ligand-Gated Ion Channels}

These are gated by the binding of a specific ligand to a site within the ion channel complex. Only a limited number of this type of channel have been reported to interact with oxysterols: the P2X7 purinoreceptor (P2X7R), the N-methyl-D-aspartate receptor (NMDAR) subtype $2 \mathrm{~B}$ (encoded by GRIN2B) and the $\mathrm{GABA}_{\mathrm{A}}$ Rs.

\subsubsection{The P2X7 Purinoreceptor (P2X7R)}

$\mathrm{P} 2 \mathrm{X7R}$ is a member of the P2X family of purinoreceptors that bind ATP, opening a non-selective cation channel that is highly permeable to $\mathrm{Ca}^{2+}$. P2X7R monomers contain two transmembrane helices and a cytoplasmic $\mathrm{C}$-terminus that is extended relative to other members of the P2X family. P2X7R is distinct from other members of its family in that it is formed only by homotrimeric complexes, as opposed to heterotrimeric ones, and in that it binds ATP with low affinity. When stimulated by low concentrations of ATP, the P2XR channel attains a conformational state that is permeable to inorganic cations. When stimulated with higher concentrations of ATP for sustained durations, the channel pore dilates, or recruits additional components, such as pannexin-1, so that it forms a pathway that is permeable to much larger organic cations [140]. This dilated pore conformation is thought to underlie the subtype-specific cytotoxicity resulting from P2X7 activation. The molecular structures of rat P2X7R in both its apo, closed state (PDB:6U9V) and ATP-bound, open state (PDB:6U9W) have been determined using cryo-electron microscopy, but these 
provide no evidence supporting a dilated pore conformation. However, these structures indicate a role for cysteine palmitoylation in maintaining the channel in a non-desensitizing state [141].

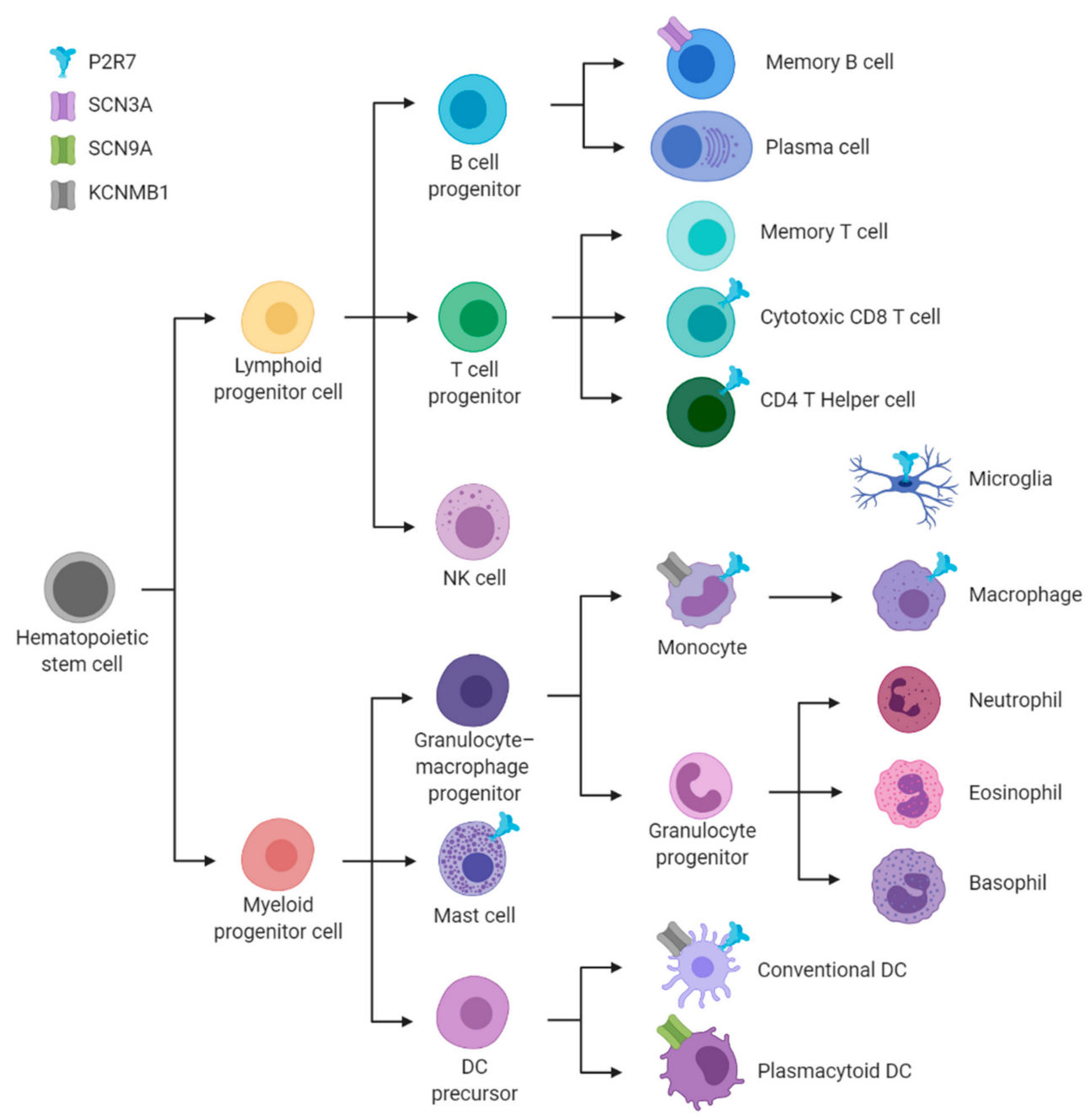

Figure 4. Overview of the key immune cell types from the hematopoietic lineage with an abstraction of their cellular expression of the ion channels discussed in this article. These channels are represented by icons of different colours: blue Figure 2. X7R, purple for SCN3A, green for SCN9A and grey for KCNMB1. This overview is derived from consensus of four independent transcriptomic data sets from human immune cells [31-33], as summarized in Supplemental Figure S1. Figure 4 was created in BioRender (BioRender.com).

P2X7R channel gating is modulated by several types of sterol. The depletion of cholesterol from the plasma membranes of cells transfected with P2X7R increases permeation of organic cations, whereas cholesterol loading inhibits this mechanism. An $\mathrm{N}$-terminal domain and multiple cholesterol recognition amino acid consensus motifs near the C-terminus are key determinants of this cholesterol sensitivity [142]. Vitamin D (1,25-dihydroxycholesterol) rapidly increases in $\mathrm{Ca}^{2+}$ in peripheral blood mononuclear cells via a mechanism dependent on P2X7R [143], but it is not known if this effect is mediated by binding to the same sites as cholesterol. There is also evidence that oxysterols modify the gating of P2X7R channels. In a model of human skin, 25-HC promotes both caspase-dependent apoptosis and pyroptosis via a P2X7R-dependent mechanism [144]. In human retinal pigment epithelial cells, both 7KC and 25-HC activate P2X7R, with the latter oxysterol requiring pannexin-1 for this effect [145]. 
P2X7R is present in many cells of the immune system, with the highest levels in monocytes, followed by NK cells and $\mathrm{CD}^{+}$memory $\mathrm{T}_{\text {reg }}$ cells; Figure 4 and Supplemental Figure S1. The roles of oxysterols in modifying P2X7R responses in immune cells are yet to be elucidated. This receptor plays a key role, as in the recognition of extracellular ATP, an archetypal damage associated molecular pattern (DAMP) molecule that is released from injured cells [146]. In monocytes, the acute stimulation of P2X7R enhances the secretion of IL-1 $\beta$ [147], whereas sustained activation promotes apoptotic cell death. Extracellular ATP promotes the activation of the NLRP3-inflammosome in monocytes and this process is impaired during sepsis [148].

Substantial experimental evidence supports the roles of P2X7R in T-lymphocyte biology [149]. P2X7R antagonists inhibit the TCR-dependent activation of mouse T cells, as assessed by their effect on IL-2 production [150]. Through P2X7R, ATP inhibits both the differentiation of naïve $\mathrm{CD}^{+}$cells into regulatory $\mathrm{CD} 4^{+} \mathrm{CD} 25^{+} \mathrm{T}$ cells $\left(\mathrm{T}_{\text {reg }}\right)$ and the immunosuppressive capabilities of this subtype [151]. The activation of P2X7R drives the decision for differentiation to an $\alpha \beta$ rather than a $\gamma \delta$ TCR phenotype [152]. Human $\mathrm{CD}^{+} \mathrm{CD}^{2} 5 \mathrm{RO}^{+}$memory $\mathrm{T}$ cells indirectly inhibit NLRP3 inflammasome activation in ATP-stimulated monocytes, via downregulation of P2X7R [153]. In response to Plasmodium chabaudi malaria infection, P2X7R stimulates Th-cell differentiation and decreases the Tfh subset [154]. Extracellular ATP promotes metabolic fitness in long-lived CD8 ${ }^{+}$memory T cells, through a mechanism involving P2X7R and AMP-activated protein kinase [155]. P2X7R stimulates non-classical secretion in numerous cell types, including $\mathrm{T}$ lymphocytes [156]. It also impairs the MHC-I-dependent presentation of oligopeptides by antigen presenting cells, thereby suppressing the activation of $\mathrm{CD} 8^{+} \mathrm{T}$ cells [157]. ATP drives apoptotic death in thymocytes via the activation of P2X7R. This receptor also underlies inflammation in a model of colitis, by promoting apoptosis in $\mathrm{T}_{\text {reg }}$ cells [158].

\subsubsection{Ionotropic Glutamate Receptors}

Glutamate is the most abundant excitatory neurotransmitter in the mammalian central nervous system. Receptors for glutamate are divided between those that are ionotropic, containing an intrinsic ion channel, and metabotropic GPCRs. Ionotropic glutamate receptors are named after their definitive pharmacological ligands: $N$-methyl-D-aspartate (NMDA), $\gamma$-amino butyric acid (GABA) and $\alpha$-amino-3-hydroxy-5-methyl-4-isoxazolepropionic acid (AMPA). Endogenous agonists of NMDAR channel complexes are glutamate, D-serine and/or glycine, depending on their subunit composition. They are heterotetrameric channel complexes, usually consisting of two obligatory GluN1 subunits (encoded by GRIN1) and two GluN2A, GluN2B, GluN2C, or GluN2D subunits (GRIN2A, GRIN2B, GRIN2C, or GRIN2D). Two alternative subunits, GluN3A and GluN3B (GRIN3A, GRIN3B), can combine with GluN1 to form a complex that has reduced current, which is gated by glycine and not by glutamate [159-161]. The opening of NMDAR channels usually results in the influx of $\mathrm{Ca}^{2+}$ and $\mathrm{Na}^{+}$, and an efflux of $\mathrm{K}^{+}$. In vivo, the permeation pathway can be blocked by $\mathrm{Mg}^{2+}$, with this inhibition being relieved by depolarization. NMDARs are predominantly present in the central nervous system, where they act as post-synaptic glutamate receptors. They have also been identified in multiple peripheral, non-neuronal cell-types [162,163]. The presence of NMDARs in cell types that circulate in the blood is potentially problematic, since the concentrations of amino acid agonists in the extracellular fluid far exceed those required for the maximal opening of these channels. This situation would result in the excessive influx of $\mathrm{Ca}^{2+}$ and consequent cytotoxicity. This issue may be resolved by peripheral cells producing NMDARs that are less sensitive to such stimuli, either through alternate splicing of the mRNA(s) encoding their subunits, distinctive assembles of subunits, or by the presence of additional inhibitory modulators that do not operate in the nervous system [162].

NMDARS are modulated by oxysterols. The most abundant cholesterol metabolite in the brain is 24(S)-HC, which is sometimes referred to as cerebrosterol. This oxysterol potentiates NMDAR-dependent excitatory post-synaptic currents (EPSCs) in rat hippocam- 
pal neurons at submicrolar concentrations; an effect that was not caused by unmodified cholesterol, or by other oxysterols, at concentrations up to $10 \mu \mathrm{M}$. 24(S)-HC did not modify the gating of other ionotropic glutamate receptors, the GABA receptors and AMPA receptors [164]. SGE-201, a synthetic analogue of 24(S)-HC, influenced the electrophysiological properties of NMDARs present either in single neurons, heterologously expressed in Xenopus oocytes, or within hippocampal slices [165]. 24(S)-HC is produced in the central nervous system by the action of CYP46A1 on cholesterol. In hippocampal slices from CYP46A1-/knockout mice, both the concentration of 24(S)-HC and the basal activity of NMDARs are greatly reduced relative to those from wildtype animals [166]. Use of chimeric receptors to map the binding of positive allosteric modulators to NMDARs indicates that 24(S)-HC interacts with the transmembrane domains of these proteins, at a binding site distinct from those of pregnenolone sulfate, or of docosahexaenoic acid [167]. In mouse hippocampal slices, the GluN2B-selective antagonist Ro25-6981 blocked the 24(S)-HC enhancement of NMDAR-dependent currents, whereas the GluN2A antagonist PEAQX did not [168]. Although 25-HC weakly potentiated NMDAR currents when administered alone, it noncompetitively inhibited the potentiation elicited by $24(\mathrm{~S})-\mathrm{HC}$. This suggests the presence of two distinct binding sites for oxysterol modulators within NMDAR complexes [169]. In an oxygen-glucose deprivation model of ischemia, 24(S)-HC exacerbates neuronal death, whereas 25-HC opposes it and can reverse the effects of 24(S)-HC [169]. Another oxysterol congener, 27-HC, reduces NMDAR protein levels in mouse brain, possibly through the downregulation of the activity-regulated cytoskeleton-associated protein (Arc), required for trafficking of these channels to the cell-surface [170].

Negative modulation of NMDARs by some oxysterol congeners might provide an explanation for an absence of cytotoxicity in immune cells, in the face of high concentrations of excitatory amino acids encountered in the blood. NMDARs are present in some immune cells, as reviewed by Boldyrev in 2005 [171]. Using fluorescence-activated cytometry, GluN1 was detected in human peripheral lymphocytes, with the activation of NMDARs in these cells being associated with $\mathrm{Ca}^{2+}$ influx, ROS production and cell death. In NK cells derived from this population, NMDA had no effect on IFN- $\gamma$ production, but suppressed that stimulated by IL-2 [172]. In mouse splenic B-lymphocytes, non-competitive NMDAR antagonists reduced proliferation, chemotaxis and immunoglobulin secretion, but enhanced IL-10 production. However, these antagonists block $\mathrm{K}^{+}$currents through voltage-gated $\mathrm{K}_{\mathrm{v}} 1.3$ and $\mathrm{K}_{\mathrm{Ca}} 3.1$ present in these and other immune cells (see Sections 3.2.1.1 and 3.3.1) $[173,174]$. These observations highlight the need for caution when interpreting the effects of small molecule drugs on immune cells.

\subsubsection{Ionotropic $\mathrm{GABA}_{\mathrm{A}} \mathrm{Rs}$}

As described in Section 2.4, GABA is the predominant central inhibitory neurotransmitter, which exerts its effects via both metabotropic $\left(G_{A B A_{B}} R\right)$ and ionotropic $\left(G_{A B A_{A}} R\right)$ receptors. $\mathrm{GABA}_{\mathrm{A}} \mathrm{R}$ complexes are pentameric in structure, with 19 distinct genes encoding subunits, and possess an intrinsic chloride channel [175]. Although no evidence for the effects of oxysterols on the gating of $\mathrm{GABA}_{\mathrm{A}} \mathrm{Rs}$ has been reported to date, these channels are modulated by neurosteroids, such as progesterone, allopregnanolone, and their synthetic analogues [176]. GABA $\mathrm{R}$ regulates multiple aspects of immune function, including the migration of DC and the activation of T lymphocytes [177].

\subsection{Voltage-Gated Ion Channels}

Voltage-gated ion channels respond to changes in membrane potential in the order of a few tens of millivolts. This allows for the flow of ions, altering membrane potential, in addition to the transfer of electrolytes and, in some cases, the influx of the second messenger $\mathrm{Ca}^{2+}[15]$. This class of channel are often extremely selective in terms of the ions that they conduct, relative to other channel families. Voltage-gated ion channels regulate diverse processes, including secretion, cell motility and the generation of action potentials. 
Two types of voltage-gated ion channels are known to be modulated by oxysterols: voltagegated potassium channels and voltage-gated sodium channels.

\subsubsection{Voltage-Gated Potassium Channels}

There is considerable evidence to support roles of voltage-gated $\mathrm{K}^{+}$channels in immune cell function. These channels are present in most cell types and regulate multiple aspects of physiology, including membrane potential, secretion, cell volume and death. They are formed from tetrameric complexes that interact with a range of accessory proteins. Voltage-gated $\mathrm{K}^{+}$channels are diverse in terms of their structures, electrophysiology and pharmacology. To date, of the voltage-gated $\mathrm{K}^{+}$channel family, only $\mathrm{K}_{\mathrm{v}} 3.1$ (belonging to the Shaw, or $\mathrm{C}$, subfamily and encoded by $K C N C 1$ ) and $\mathrm{K}_{\mathrm{Ca}} 1.1$ (Slo-1, or large conductance calcium-activated potassium channel, subfamily $\mathrm{M}$, alpha member 1 , encoded by KCNMA1) have been reported to be modulated by oxysterols. Since it is gated by a combination of membrane depolarization and increased cytoplasmic $\mathrm{Ca}^{2+}, \mathrm{K}_{\mathrm{Ca}} 1.1$ will be discussed in greater detail in Section 3.3.1, on channels opened by multiple stimuli.

\subsubsection{1. $\mathrm{K}_{\mathrm{v}} 3.1$}

The $\mathrm{K}_{\mathrm{v}} 3$ family of voltage-gated $\mathrm{K}^{+}$channels was originally identified as the Shaw family in the fruit-fly Drosophila melanogaster and consists of three distinct genes encoding $\mathrm{K}_{\mathrm{v}} 3.1, \mathrm{~K}_{\mathrm{v}} 3.2$ and $\mathrm{K}_{\mathrm{v}} 3.3$. Electrophysiologically, this family differs from other voltagegated $\mathrm{K}^{+}$channels in terms of activation at more positive membrane potentials and rapid inactivation. In neurons, these properties mean that $\mathrm{K}_{\mathrm{v}} 3$ channels contribute to rapid, repetitive firing of action potentials and, when mutated, to epilepsy [178]. $\mathrm{K}_{\mathrm{v}} 3.1$ is produced as two alternately spliced variants, $\mathrm{K}_{\mathrm{v}} 3.1 \mathrm{a}$ and $\mathrm{K}_{\mathrm{v}} 3.1 \mathrm{~b}$, differing at the C-terminus. Of these, $\mathrm{K}_{\mathrm{v}} 3.1 \mathrm{~b}$ is known to be modulated by oxysterols. In both $158 \mathrm{~N}$ oligodendrocyte and BV-2 microglial cell lines, incubation with either $24(\mathrm{~S})-\mathrm{HC}$ or $7 \mathrm{KC}$ for $48 \mathrm{~h}$ decreased $\mathrm{K}_{\mathrm{v}} 1.3 \mathrm{~b}$ protein abundance and function [179]. $\mathrm{K}_{\mathrm{v}} 1.3$ is responsible for the "I- $\mathrm{K}^{+}$current" and is transcribed at very low levels in cytotoxic T cells, but at high levels in a CD4-CD8 ${ }^{-}$Thy $1^{+} \mathrm{T}$ lymphocytes from mice with autoimmune disease [180].

\subsubsection{Voltage-Gated Sodium Channels}

Voltage-gated $\mathrm{Na}^{+}$channels have a canonical role in underlying action potentials in excitable tissues, but regulate cell-volume, motility, secretion and death in other cell types. They are comprised of a channel-forming, voltage-sensing $\alpha$ subunit $\left(\mathrm{Na}_{\mathrm{v}} 1.1-1.5\right.$ encoded by $S C N 1 A-S C N 5 A, \mathrm{Na}_{\mathrm{v}} 1.6$ encoded by $S C N 8 A, \mathrm{Na}_{\mathrm{v}} 1.7-1.8$ encoded by SCN9ASCN11A, and $\mathrm{Na}_{x}$ encoded by SCN7A) in combination with accessory proteins, such as the $\beta$-sub-units $\left(\mathrm{Na}_{\mathrm{v}} \beta 1-4\right.$ encoded by $\left.S C N 1 B-S C N 4 B\right)$, which influence channel gating or trafficking [181]. Canonical antagonists of these channels include the puffer-fish toxin, tetrodotoxin (TTX), and the small molecule drug, amiloride. Since voltage-gated $\mathrm{Na}^{+}$ channels are present in lymphocyte- and monocyte-derived immune cells, there is potential for small molecule modulators of these channels to be utilized as immunotherapeutic drugs. This is offset by potentially severe side-effects of such drugs on the nervous system [182].

There is strong evidence for the modulation of voltage-gated $\mathrm{Na}^{+}$channels by oxysterols [183]. In dorsal root ganglion neurons, the TTX-resistant $\mathrm{Na}_{\mathrm{v}} 1.8$ protein is distributed in clusters, thought to be lipid rafts. This localization was disrupted by either the cholesterol-chelator methyl- $\beta$-cyclodextrin, or by the oxysterol $7 \mathrm{KC}$, and was associated with a loss of neuronal excitability [184]. At micromolar concentrations, the oxysterol, cholestane- $3 \beta, 5 \alpha, 6 \beta$-triol (triol) reduces $\mathrm{Na}^{+}$current density in rat hippocampal pyramidal neurons and ablated seizures in a kainate-induced mouse model of epilepsy [185]. Molecular modelling of voltage-gated $\mathrm{Na}^{+}$channels from the bacteria Arcobacter butzleri and Magnetococcus marinus indicates that triol binds to the indole ring of tryptophan 122 within the channel pore [186].

As assessed by flow cytometry, the voltage-gated $\mathrm{Na}^{+}$channel inhibitors batrachotoxin or veratridine depolarized a subset of human NK cells [187]. In human HLA-DR-restricted 
$\mathrm{CD}^{+} \alpha \beta$ T cells, stimulation with a non-self-antigenic peptide elicited a $\mathrm{Na}^{+}$current that could be blocked with amiloride, though not with TTX [188]. In contrast, voltagegated $\mathrm{Na}^{+}$currents detected in human peripheral blood mononuclear cells and in acute lymphocytic leukemia cell lines were largely inhibited by TTX and probably involved $\mathrm{Na}_{\mathrm{v}} 1.3, \mathrm{Na}_{\mathrm{v}} 1.6$, or $\mathrm{Na}_{\mathrm{v}}$ 1.7. TTX also inhibited the invasiveness of Jurkat and MOLT-4 cell lines [189]. The expression levels of $\mathrm{Na}_{\mathrm{v}} 1.5$ underlie differences in TCR-mediated responses to Listeria antigens in two CD4 ${ }^{+}$T-cell lines [190]. Immature dendritic cells (DC) possess voltage-gated $\mathrm{Na}^{+}$channels, mediated predominantly by the $\mathrm{Na}_{\mathrm{v}} 1.7$ subtype, which is downregulated upon differentiation [191].

Voltage-gated $\mathrm{Na}^{+}$channels, mainly those containing $\mathrm{Na}_{\mathrm{v}} 1.1, \mathrm{Na}_{\mathrm{v}} 1.5$ or $\mathrm{Na}_{\mathrm{v}} 1.6$, also regulate the physiology of monocytes, macrophages and microglia [192]. $\mathrm{Na}_{\mathrm{V}} 1.5$, a subtype originally identified in the cell-surface membrane of cardiomyocytes, is located in the late endosomes of human monocytes and macrophages, where it permits $\mathrm{Na}^{+}$efflux from these organelles and decreases their $\mathrm{pH}$ [193]. In macrophages, these endosomal $\mathrm{Na}_{\mathrm{v}} 1.5$ channels also regulate phagocytosis of mycobacteria [194] and initiation of innate immune responses triggered by double-stranded RNA [195]. In macrophages, alternatelyspliced variants of SCN5A and SCN10A promote the expression and protein abundance of serine/threonine-protein phosphatase 1 regulatory subunit 10 (PPP1R10), a DNA repair enzyme postulated to limit damage to host cells during inflammatory responses [196]. Knockdown of voltage-gated $\mathrm{Na}^{+}$channels using RNA interference reduced proliferation, migration and phagocytosis by the RAW264.7 macrophage cell line. This also reduced macrophage proliferation in atherosclerotic plaques [197].

\subsection{Ion Channels Gated by Multiple Stimuli}

Certain families of ion channels are gated by multiple stimuli. Ion channels known to be modulated by oxysterols are $\mathrm{Ca}^{2+}$ and voltage-dependent $\mathrm{K}^{+}$channels and transient receptor potential, canonical, subtype 1 (TRPC1) cation channels.

\subsection{1. $\mathrm{Ca}^{2+}$ and Voltage-Dependent $\mathrm{K}^{+}$Channels}

The opening of a subset of voltage-gated $\mathrm{K}^{+}$channels is stimulated by increased cytoplasmic $\mathrm{Ca}^{2+}$ concentrations. A well-characterized member of this family is called $\mathrm{K}_{\mathrm{Ca}} 1.1$, or Slo-1, the large-conductance $\mathrm{K}^{+}$channel $\mathrm{BK}$, or MaxiK and is encoded by the calcium-activated $\mathrm{K}^{+}$channel subunit, subfamily $\mathrm{M}$, alpha-1 (KCNMA1) gene. BK channels are formed from tetrameric assemblies of $\mathrm{K}_{\mathrm{Ca}} 1.1$ protein and their electrophysiology, trafficking and interactions with ligands are modulated by associations with accessory proteins, most notably $\beta$ and $\gamma$ subunits [198]. A key component of $\mathrm{K}_{\mathrm{Ca}} 1.1$ gating is a switch from positively charged amino acids (the "RKK ring") binding to negatively charged glutamate residues in the protein when in a closed state, to binding oxygen atoms of membrane lipids when in an open state. This gating mechanism helps explain the modulation of BK channel gating by lipophilic modulators [199]. BK gating can be modulated by cholesterol and by bile acids that interact with the channel complex at distinct sites, including at the $\beta 1$ subunits [200].

Oxysterols modulate BK channel gating. At micromolar concentrations, the side-chain oxysterols 20(S)-HC, 22(R)-HC, 24(S)-HC, 25-HC and 27-HC all inhibited $\mathrm{K}^{+}$currents through $\mathrm{K}_{\mathrm{Ca}} 1.1$, whereas the ring-modified oxysterols, $7-\mathrm{KC}$ or $7 \alpha-\mathrm{HC}$ did not [201]. The inhibition of BK by 24(R)-HC is distinct from that exerted by its enantiomer 24(S)-HC in terms of activation kinetics and voltage dependency. The auxiliary subunits of BK channels can also be modulated by oxysterols. Within atherosclerotic lesions, 7KC downregulates KCNB1 (the $\beta 1$ subunit of BK) [202].

BK channels play important roles in the innate immune system. Monocyte adhesion to endothelial cells elicited by lysophosphatidylcholine is dependent on these $\mathrm{K}^{+}$channels [203]. In macrophages, the blockade of BK inhibits the IкB- and NF- $\mathrm{KB}$-dependent inflammatory pathways stimulated by LPS [204]. BK is not exclusively located in the cell-surface membrane. In macrophages, lysosomal BK channels promote large-particle 
phagocytosis, by facilitating the release of $\mathrm{Ca}^{2+}$ from endolysosomal stores [205]. In the RAW264.7 macrophage cell line, nuclear BK regulates the phosphorylation of the transcription factor cyclic AMP response element binding protein (CREBP) [206].

\subsubsection{Transient Receptor Potential Channels}

Transient receptor potential channels (TRPs) were originally identified in Drosophila melanogaster photoreceptors. In mammals, homologues of this trp channel form a family of over thirty genes. They are all homo- or hetero-tetrameric in structure, conducting monovalent cations and in most cases, $\mathrm{Ca}^{2+}$. In humans, there are six functional members of the canonical TRP family, TRPC1-TRPC7, with TRPC2 considered to be a pseudogene. Similar to other members of the TRP family, TRPCs are gated by multiple stimuli, often acting in concert. A canonical stimulus for TRP gating is activation of PLC, but neither of the products of this enzyme ( $\mathrm{IP}_{3}$ and DAG) gate these channels. Depletion of $\mathrm{ER} \mathrm{Ca}^{2+}$ stores via $\mathrm{IP}_{3} \mathrm{R}$ channels activates TRP channels, possibly by interaction with another class of store-operated $\mathrm{Ca}^{2+}$-entry channels, Orai. TRPC1 is also reported to be gated by mechanical stimuli and, when in heterotetrameric complexes with TRPC5, by sphingosine1-phosphate [207].

There is limited evidence of roles for oxysterols in the regulation of TRPC1 gating. In the THP-1 monocytic cell line 7-KC stimulates translocation of TRPC1 to lipid rafts, with subsequent $\mathrm{Ca}^{2+}$-dependent inhibition of the Bcl-2 antagonist of cell death [208]. Similarly, in vascular smooth muscle cells, oxidized low-density lipoprotein (oxLDL) causes celldeath that can be inhibited by TRPC1 knockdown and which is associated with $\mathrm{Ca}^{2+}$ influx. Treatment with oxLDL causes an increase in 7KC within the caveolae of these cells, along with the translocation of TRPC1 to these membrane invaginations [209].

TRPC1 has been detected in diverse immune cells. For example, using reverse transcription PCR, in human peripheral blood leukocytes, $\mathrm{CD}^{+} \mathrm{T}$ cells and the Jurkat $\mathrm{T}$ lymphoma were found [210]. Knockout of TRPC1 in neutrophils impairs their migration and chemotaxis [211]. M1 macrophage polarization is dependent on TRPC1-mediated $\mathrm{Ca}^{2+}$ entry [212]. In addition, the inhibition of TRPC1-mediated $\mathrm{Ca}^{2+}$ entry promotes ER stress in the RAW264.7 macrophage cell line, initiating inflammatory responses [213]. In primary microglia, soluble factors from the helminth Mesocestoides corti inhibit $\mathrm{Ca}^{2+}$ influx via TRPC1, suppressing immune responses; oxysterols are candidates for these soluble molecules [214].

\section{Conclusions and Perspectives}

Cells of the immune system contain multiple GPCRs and ion channels that are modulated by oxysterols. However, in many cases, it is unclear if these signalling proteins are influenced by cholesterol oxidation products in vivo under physiological or pathological settings. Similarly, many of the consequences of oxysterol modulation of GPCRs and ion channels within the immune system have not been investigated. Furthermore, the molecular mechanisms by which oxysterols alter the function of many of these receptors awaits full characterization. Consequently, there is considerable scope for exploration of cell-surface receptors for oxysterols in the immune system, both for scientific discovery and for the development of new immunotherapeutic regimes.

Supplementary Materials: The following are available online at https:/ / www.mdpi.com/article/ 10.3390/cells10082078/s1, Figure S1: Expression of receptor for oxysterols during hematopoietic differentiation and on immune cells, Figure S2: A review of the scientific literature.

Author Contributions: This review was conceptualized by the corresponding authors, M.R. and J.M. The original draft of this review was prepared by L.R., M.R. and J.M., with all authors contributing to the refinement, revision and final preparation of this work. C.-C.H. and J.H. investigated, curated, analysed and visualised transcriptomic data. All authors contributed to literature review, critical assessment published work and its synthesis. L.R., C.-C.H. and J.M. generated the figures. J.M. contributed article publication charges. All authors have read and agreed to the published version of the manuscript. 
Funding: C.-C.H. and J.H. are supported by the German Research Foundation (FOR 2149). For this project, J.M. was supported by the Department of Physiology, University College Cork, funded by the Higher Education Authority of Ireland.

Institutional Review Board Statement: Not applicable.

Informed Consent Statement: Not applicable.

Acknowledgments: J.M. thanks members of the European Network for Oxysterols Research for useful discussions. All authors thank the reviewers of this article, for their contributions to improving the accepted version.

Conflicts of Interest: The authors declare no conflict of interest.

\section{References}

1. Luu, W.; Sharpe, L.J.; Capell-Hattam, I.; Gelissen, I.C.; Brown, A.J. Oxysterols: Old Tale, New Twists. Annu. Rev. Pharm. Toxicol. 2016, 56, 447-467. [CrossRef]

2. Kloudova, A.; Guengerich, F.P.; Soucek, P. The Role of Oxysterols in Human Cancer. Trends Endocrinol. Metab. 2017, 28, 485-496. [CrossRef] [PubMed]

3. Zmysłowski, A.; Szterk, A. Current knowledge on the mechanism of atherosclerosis and pro-atherosclerotic properties of oxysterols. Lipids Health Dis. 2017, 16, 188. [CrossRef] [PubMed]

4. Choi, C.; Finlay, D.K. Diverse Immunoregulatory Roles of Oxysterols-The Oxidized Cholesterol Metabolites. Metabolites 2020, 10, 384. [CrossRef]

5. Duc, D.; Vigne, S.; Pot, C. Oxysterols in Autoimmunity. Int. J. Mol. Sci. 2019, 20, 4522. [CrossRef]

6. Spann, N.J.; Glass, C.K. Sterols and oxysterols in immune cell function. Nat. Immunol. 2013, 14, 893-900. [CrossRef]

7. Massey, J.B. Membrane and protein interactions of oxysterols. Curr. Opin. Lipidol. 2006, 17, 296-301. [CrossRef]

8. Zang, R.; Case, J.B.; Yutuc, E.; Ma, X.; Shen, S.; Castro, M.F.G.; Liu, Z.; Zeng, Q.; Zhao, H.; Son, J.; et al. Cholesterol 25-hydroxylase suppresses SARS-CoV-2 replication by blocking membrane fusion. Proc. Natl. Acad. Sci. USA 2020, 117, 32105-32113. [CrossRef] [PubMed]

9. Domingues, M.; Gomes, B.; Hollmann, A.; Santos, N. 25-Hydroxycholesterol Effect on Membrane Structure and Mechanical Properties. Int. J. Mol. Sci. 2021, 22, 2574. [CrossRef]

10. Ghzaiel, I.; Sassi, K.; Zarrouk, A.; Nury, T.; Ksila, M.; Leoni, V.; Bouhaouala-Zahar, B.; Hammami, S.; Hammami, M.; Mackrill, J.J.; et al. 7-Ketocholesterol: Effects on viral infections and hypothetical contribution in COVID-19. J. Steroid Biochem. Mol. Biol. 2021, 212, 105939. [CrossRef] [PubMed]

11. Abrams, M.E.; Johnson, K.; Perelman, S.S.; Zhang, L.-S.; Endapally, S.; Mar, K.B.; Thompson, B.M.; McDonald, J.G.; Schoggins, J.W.; Radhakrishnan, A.; et al. Oxysterols provide innate immunity to bacterial infection by mobilizing cell surface accessible cholesterol. Nat. Microbiol. 2020, 5, 929-942. [CrossRef]

12. Antonny, B.; Bigay, J.; Mesmin, B. The Oxysterol-Binding Protein Cycle: Burning Off PI(4)P to Transport Cholesterol. Annu. Rev. Biochem. 2018, 87, 809-837. [CrossRef] [PubMed]

13. Pietrangelo, A.; Ridgway, N.D. Bridging the molecular and biological functions of the oxysterol-binding protein family. Cell. Mol. Life Sci. 2018, 75, 3079-3098. [CrossRef] [PubMed]

14. Olkkonen, V.M. OSBP-Related Protein Family in Lipid Transport over Membrane Contact Sites. Lipid Insights 2015, 8s1, LPI-S31726. [CrossRef]

15. Mackrill, J.J. Oxysterols and calcium signal transduction. Chem. Phys. Lipids 2011, 164, 488-495. [CrossRef]

16. Zhong, W.; Yi, Q.; Xu, B.; Li, S.; Wang, T.; Liu, F.; Zhu, B.; Hoffmann, P.R.; Ji, G.; Lei, P.; et al. ORP4L is essential for T-cell acute lymphoblastic leukemia cell survival. Nat. Commun. 2016, 7, 12702. [CrossRef]

17. Cao, X.; Chen, J.; Li, D.; Xie, P.; Xu, M.; Lin, W.; Li, S.; Pan, G.; Tang, Y.; Xu, J.; et al. ORP4L couples IP3to ITPR1 in control of endoplasmic reticulum calcium release. FASEB J. 2019, 33, 13852-13865. [CrossRef]

18. Lessmann, E.; Ngo, M.; Leitges, M.; Minguet, S.; Ridgway, N.D.; Huber, M. Oxysterol-binding protein-related protein (ORP) 9 is a PDK-2 substrate and regulates Akt phosphorylation. Cell. Signal. 2007, 19, 384-392. [CrossRef]

19. Strating, J.; Van Der Linden, L.; Albulescu, L.; Bigay, J.; Arita, M.; Delang, L.; Leyssen, P.; Van Der Schaar, H.M.; Lanke, K.H.; Thibaut, H.J.; et al. Itraconazole Inhibits Enterovirus Replication by Targeting the Oxysterol-Binding Protein. Cell Rep. 2015, 10, 600-615. [CrossRef] [PubMed]

20. Ma, L.; Nelson, E.R. Oxysterols and nuclear receptors. Mol. Cell. Endocrinol. 2019, 484, 42-51. [CrossRef]

21. Korf, H.; Beken, S.V.; Romano, M.; Steffensen, K.; Stijlemans, B.; Gustafsson, J.; Grooten, J.; Huygen, K. Liver X receptors contribute to the protective immune response against Mycobacterium tuberculosis in mice. J. Clin. Investig. 2009, 119, $1626-1637$. [CrossRef] [PubMed]

22. A DeBose-Boyd, R.; Brown, M.S.; Li, W.-P.; Nohturfft, A.; Goldstein, J.L.; Espenshade, P.J. Transport-Dependent Proteolysis of SREBP: Relocation of Site-1 Protease from Golgi to ER Obviates the Need for SREBP Transport to Golgi. Cell 1999, 99, 703-712. [CrossRef] 
23. Gong, Y.; Lee, J.N.; Brown, M.S.; Goldstein, J.L.; Ye, J. Juxtamembranous aspartic acid in Insig-1 and Insig-2 is required for cholesterol homeostasis. Proc. Natl. Acad. Sci. USA 2006, 103, 6154-6159. [CrossRef] [PubMed]

24. Wang, Y.; Kumar, N.; Crumbley, C.; Griffin, P.R.; Burris, T.P. A second class of nuclear receptors for oxysterols: Regulation of ROR $\alpha$ and ROR $\gamma$ activity by 24S-hydroxycholesterol (cerebrosterol). Mol. Cell Biol. Lipids 2010, 1801, 917-923. [CrossRef]

25. DuSell, C.D.; Umetani, M.; Shaul, P.W.; Mangelsdorf, D.; McDonnell, D.P. 27-Hydroxycholesterol Is an Endogenous Selective Estrogen Receptor Modulator. Mol. Endocrinol. 2008, 22, 65-77. [CrossRef]

26. Umetani, M.; Domoto, H.; Gormley, A.K.; Yuhanna, I.S.; Cummins, C.; Javitt, N.B.; Korach, K.; Shaul, P.W.; Mangelsdorf, D. 27-Hydroxycholesterol is an endogenous SERM that inhibits the cardiovascular effects of estrogen. Nat. Med. 2007, 13, 1185-1192. [CrossRef]

27. Wang, Y.; Chen, L.; Pandak, W.M.; Heuman, D.; Hylemon, P.B.; Ren, S. High Glucose Induces Lipid Accumulation via 25Hydroxycholesterol DNA-CpG Methylation. iScience 2020, 23, 101102. [CrossRef]

28. Bauman, D.R.; Bitmansour, A.D.; McDonald, J.G.; Thompson, B.; Liang, G.; Russell, D.W. 25-Hydroxycholesterol secreted by macrophages in response to Toll-like receptor activation suppresses immunoglobulin A production. Proc. Natl. Acad. Sci. USA 2009, 106, 16764-16769. [CrossRef]

29. Sanchez, L.D.; Pontini, L.; Marinozzi, M.; Sanchez-Aranguren, L.C.; Reis, A.; Dias, I.H. Cholesterol and oxysterol sulfates: Pathophysiological roles and analytical challenges. Br. J. Pharm. 2020, 178, 3327-3341. [CrossRef]

30. Wang, Y.; Lin, W.; Brown, J.E.; Chen, L.; Pandak, W.M.; Hylemon, P.B.; Ren, S. 25-Hydroxycholesterol 3-sulfate is an endogenous ligand of DNA methyltransferases in hepatocytes. J. Lipid Res. 2021, 62, 100063. [CrossRef] [PubMed]

31. Wang, Y.; Li, X.; Ren, S. Cholesterol Metabolites 25-Hydroxycholesterol and 25-Hydroxycholesterol 3-Sulfate Are Potent Paired Regulators: From Discovery to Clinical Usage. Metabolites 2020, 11, 9. [CrossRef]

32. Bottemanne, P.; Paquot, A.; Ameraoui, H.; Guillemot-Legris, O.; Alhouayek, M.; Muccioli, G.G. 25-Hydroxycholesterol metabolism is altered by lung inflammation, and its local administration modulates lung inflammation in mice. FASEB J. 2021, 35, e21514. [CrossRef] [PubMed]

33. Jiang, W.; Miyamoto, T.; Kakizawa, T.; Nishio, S.-I.; Oiwa, A.; Takeda, T.; Suzuki, S.; Hashizume, K. Inhibition of LXR $\alpha$ signaling by vitamin D receptor: Possible role of VDR in bile acid synthesis. Biochem. Biophys. Res. Commun. 2006, 351, 176-184. [CrossRef]

34. Wamil, M.; Andrew, R.; Chapman, K.; Street, J.; Morton, N.M.; Seckl, J.R. 7-Oxysterols Modulate Glucocorticoid Activity in Adipocytes through Competition for 11ß-Hydroxysteroid Dehydrogenase Type. Endocrinology 2008, 149, 5909-5918. [CrossRef] [PubMed]

35. Repa, J.; Liang, G.; Ou, J.; Bashmakov, Y.; Lobaccaro, J.-M.A.; Shimomura, I.; Shan, B.; Brown, M.S.; Goldstein, J.L.; Mangelsdorf, D. Regulation of mouse sterol regulatory element-binding protein-1c gene (SREBP-1c) by oxysterol receptors, LXRalpha and LXRbeta. Genes Dev. 2000, 14, 2819-2830. [CrossRef]

36. Liang, G.; Yang, J.; Horton, J.D.; Hammer, R.E.; Goldstein, J.L.; Brown, M.S. Diminished Hepatic Response to Fasting/Refeeding and Liver X Receptor Agonists in Mice with Selective Deficiency of Sterol Regulatory Element-binding Protein-1c. J. Biol. Chem. 2002, 277, 9520-9528. [CrossRef] [PubMed]

37. Maïga, A.; Lemieux, S.; Pabst, C.; Lavallée, V.-P.; Bouvier, M.; Sauvageau, G.; Hébert, J. Transcriptome analysis of G proteincoupled receptors in distinct genetic subgroups of acute myeloid leukemia: Identification of potential disease-specific targets. Blood Cancer J. 2016, 6, e431. [CrossRef] [PubMed]

38. Schmiedel, B.J.; Singh, D.; Madrigal, A.; Valdovino-Gonzalez, A.G.; White, B.M.; Zapardiel-Gonzalo, J.; Ha, B.; Altay, G.; Greenbaum, J.A.; McVicker, G.; et al. Impact of Genetic Polymorphisms on Human Immune Cell Gene Expression. Cell 2018, 175, 1701-1715. [CrossRef]

39. Villani, A.-C.; Satija, R.; Reynolds, G.; Sarkizova, S.; Shekhar, K.; Fletcher, J.; Griesbeck, M.; Butler, A.; Zheng, S.; Lazo, S.; et al. Single-cell RNA-seq reveals new types of human blood dendritic cells, monocytes, and progenitors. Science 2017, 356, eaah4573. [CrossRef]

40. Rosenkilde, M.M.; Benned-Jensen, T.; Andersen, H.; Holst, P.J.; Kledal, T.N.; Luttichau, H.R.; Larsen, J.K.; Christensen, J.; Schwartz, T.W. Molecular Pharmacological Phenotyping of EBI2. J. Biol. Chem. 2006, 281, 13199-13208. [CrossRef]

41. Yi, T.; Wang, X.; Kelly, L.M.; An, J.; Xu, Y.; Sailer, A.; Gustafsson, J.-A.; Russell, D.; Cyster, J.G. Oxysterol Gradient Generation by Lymphoid Stromal Cells Guides Activated B Cell Movement during Humoral Responses. Immunity 2012, 37, 535-548. [CrossRef] [PubMed]

42. Kelly, L.M.; Pereira, J.; Yi, T.; Xu, Y.; Cyster, J.G. EBI2 Guides Serial Movements of Activated B Cells and Ligand Activity Is Detectable in Lymphoid and Nonlymphoid Tissues. J. Immunol. 2011, 187, 3026-3032. [CrossRef]

43. Gatto, M.; Wood, K.; Brink, R. EBI2 Operates Independently of but in Cooperation with CXCR5 and CCR7 To Direct B Cell Migration and Organization in Follicles and the Germinal Center. J. Immunol. 2011, 187, 4621-4628. [CrossRef] [PubMed]

44. Pereira, J.; Kelly, L.M.; Xu, Y.; Cyster, J.G. EBI2 mediates B cell segregation between the outer and centre follicle. Nat. Cell Biol. 2009, 460, 1122-1126. [CrossRef]

45. Kim, S.T.; Choi, J.-Y.; Lainez, B.; Schulz, V.P.; Karas, D.E.; Baum, E.D.; Setlur, J.; Gallagher, P.G.; Craft, J. Human Extrafollicular CD4+ Th Cells Help Memory B Cells Produce Igs. J. Immunol. 2018, 201, 1359-1372. [CrossRef]

46. Ki, S.; Thyagarajan, H.M.; Hu, Z.; Lancaster, J.N.; Ehrlich, L.I. EBI2 contributes to the induction of thymic central tolerance in mice by promoting rapid motility of medullary thymocytes. Eur. J. Immunol. 2017, 47, 1906-1917. [CrossRef] [PubMed] 
47. Baptista, A.P.; Gola, A.; Huang, Y.; Milanez-Almeida, P.; Torabi-Parizi, P.; Urban, J.; Shapiro, V.S.; Gerner, M.Y.; Germain, R.N. The Chemoattractant Receptor Ebi2 Drives Intranodal Naive CD4+ T Cell Peripheralization to Promote Effective Adaptive Immunity. Immunity 2019, 50, 1188-1201. [CrossRef]

48. Li, J.; Lu, E.; Yi, T.; Cyster, J.G. EBI2 augments Tfh cell fate by promoting interaction with IL-2-quenching dendritic cells. Nat. Cell Biol. 2016, 533, 110-114. [CrossRef]

49. Yi, T.; Cyster, J.G. EBI2-mediated bridging channel positioning supports splenic dendritic cell homeostasis and particulate antigen capture. eLife 2013, 2, e00757. [CrossRef]

50. Lu, E.; Dang, E.V.; McDonald, J.G.; Cyster, J.G. Distinct oxysterol requirements for positioning naïve and activated dendritic cells in the spleen. Sci. Immunol. 2017, 2, eaal5237. [CrossRef]

51. Chiang, E.Y.; Johnston, R.J.; Grogan, J.L. EBI2 Is a Negative Regulator of Type I Interferons in Plasmacytoid and Myeloid Dendritic Cells. PLoS ONE 2013, 8, e83457. [CrossRef]

52. Shen, Z.-J.; Hu, J.; Kashi, V.P.; Kelly, E.; Denlinger, L.C.; Lutchman, K.; McDonald, J.G.; Jarjour, N.N.; Malter, J.S. Epstein-Barr Virus-induced Gene 2 Mediates Allergen-induced Leukocyte Migration into Airways. Am. J. Respir. Crit. Care Med. 2017, 195, 1576-1585. [CrossRef] [PubMed]

53. Emgård, J.; Kammoun, H.; García-Cassani, B.; Chesné, J.; Parigi, S.M.; Jacob, J.-M.; Cheng, H.-W.; Evren, E.; Das, S.; Czarnewski, P.; et al. Oxysterol Sensing through the Receptor GPR183 Promotes the Lymphoid-Tissue-Inducing Function of Innate Lymphoid Cells and Colonic Inflammation. Immunity 2018, 48, 120-132. [CrossRef] [PubMed]

54. Wyss, A.; Raselli, T.; Perkins, N.; Ruiz, F.; Schmelczer, G.; Klinke, G.; Moncsek, A.; Roth, R.; Spalinger, M.R.; Hering, L.; et al. The EBI2-oxysterol axis promotes the development of intestinal lymphoid structures and colitis. Mucosal Immunol. 2019, 12, 733-745. [CrossRef]

55. Mutemberezi, V.; Buisseret, B.; Masquelier, J.; Guillemot-Legris, O.; Alhouayek, M.; Muccioli, G.G. Oxysterol levels and metabolism in the course of neuroinflammation: Insights from in vitro and in vivo models. J. Neuroinflamm. 2018, 15, 1-16. [CrossRef]

56. Rutkowska, A.; O'Sullivan, S.A.; Christen, I.; Zhang, J.; Sailer, A.; Dev, K.K. The EBI2 signalling pathway plays a role in cellular crosstalk between astrocytes and macrophages. Sci. Rep. 2016, 6, 25520. [CrossRef]

57. Barington, L.; Wanke, F.; Arfelt, K.N.; Holst, P.J.; Kurschus, F.C.; Rosenkilde, M.M. EBI2 in splenic and local immune responses and in autoimmunity. J. Leukoc. Biol. 2018, 104, 313-322. [CrossRef]

58. Van Der Poel, M.; Ulas, T.; Mizee, M.R.; Hsiao, C.-C.; Miedema, S.; Adelia; Schuurman, K.G.; Helder, B.; Tas, S.W.; Schultze, J.L.; et al. Transcriptional profiling of human microglia reveals grey-white matter heterogeneity and multiple sclerosis-associated changes. Nat. Commun. 2019, 10, 1139. [CrossRef]

59. Braden, K.; Giancotti, L.A.; Chen, Z.; DeLeon, C.; Latzo, N.; Boehm, T.; D'Cunha, N.; Thompson, B.M.; Doyle, T.M.; McDonald, J.G.; et al. GPR183-Oxysterol Axis in Spinal Cord Contributes to Neuropathic Pain. J. Pharm. Exp. 2020, 375, 349-357. [CrossRef] [PubMed]

60. Wanke, F.; Moos, S.; Croxford, A.L.; Heinen, A.P.; Gräf, S.; Kalt, B.; Tischner, D.; Zhang, J.; Christen, I.; Bruttger, J.; et al. EBI2 Is Highly Expressed in Multiple Sclerosis Lesions and Promotes Early CNS Migration of Encephalitogenic CD4 T Cells. Cell Rep. 2017, 18, 1270-1284. [CrossRef]

61. Clottu, A.S.; Mathias, A.; Sailer, A.W.; Schluep, M.; Seebach, J.; Du Pasquier, R.; Pot, C. EBI2 Expression and Function: Robust in Memory Lymphocytes and Increased by Natalizumab in Multiple Sclerosis. Cell Rep. 2017, 18, 213-224. [CrossRef]

62. Chalmin, F.; Rochemont, V.; Lippens, C.; Clottu, A.; Sailer, A.; Merkler, D.; Hugues, S.; Pot, C. Oxysterols regulate encephalitogenic CD4+ T cell trafficking during central nervous system autoimmunity. J. Autoimmun. 2015, 56, 45-55. [CrossRef] [PubMed]

63. Nevius, E.; Pinho, F.; Dhodapkar, M.; Jin, H.; Nadrah, K.; Horowitz, M.C.; Kikuta, J.; Ishii, M.; Pereira, J.P. Oxysterols and EBI2 promote osteoclast precursor migration to bone surfaces and regulate bone mass homeostasis. J. Exp. Med. 2015, 212, 1931-1946. [CrossRef]

64. Hannedouche, S.; Zhang, J.; Yi, T.; Shen, W.; Nguyen, D.; Pereira, J.; Guerini, D.; Baumgarten, B.U.; Roggo, S.; Wen, B.; et al. Oxysterols direct immune cell migration via EBI2. Nat. Cell Biol. 2011, 475, 524-527. [CrossRef] [PubMed]

65. Liu, C.; Yang, X.V.; Wu, J.; Kuei, C.; Mani, N.S.; Zhang, L.; Yu, J.; Sutton, S.W.; Qin, N.; Banie, H.; et al. Oxysterols direct B-cell migration through EBI2. Nat. Cell Biol. 2011, 475, 519-523. [CrossRef] [PubMed]

66. Honda, A.; Miyazaki, T.; Ikegami, T.; Iwamoto, J.; Maeda, T.; Hirayama, T.; Saito, Y.; Teramoto, T.; Matsuzaki, Y. Cholesterol 25-hydroxylation activity of CYP3A. J. Lipid Res. 2011, 52, 1509-1516. [CrossRef]

67. Griffiths, W.J.; Wang, Y. Oxysterols as lipid mediators: Their biosynthetic genes, enzymes and metabolites. Prostaglandins Other Lipid Mediat. 2019, 147, 106381. [CrossRef]

68. Park, K.; Scott, A.L. Cholesterol 25-hydroxylase production by dendritic cells and macrophages is regulated by type I interferons. J. Leukoc. Biol. 2010, 88, 1081-1087. [CrossRef]

69. Diczfalusy, U.; Olofsson, K.E.; Carlsson, A.-M.; Gong, M.; Golenbock, D.T.; Rooyackers, O.; Fläring, U.; Björkbacka, H. Marked upregulation of cholesterol 25-hydroxylase expression by lipopolysaccharide. J. Lipid Res. 2009, 50, 2258-2264. [CrossRef]

70. Preuss, I.; Ludwig, M.-G.; Baumgarten, B.; Bassilana, F.; Gessier, F.; Seuwen, K.; Sailer, A.W. Transcriptional regulation and functional characterization of the oxysterol/EBI2 system in primary human macrophages. Biochem. Biophys. Res. Commun. 2014, 446, 663-668. [CrossRef] [PubMed] 
71. Madenspacher, J.H.; Morrell, E.D.; Gowdy, K.M.; McDonald, J.G.; Thompson, B.M.; Muse, G.W.; Martinez, J.; Thomas, S.Y.; Mikacenic, C.; Nick, J.A.; et al. Cholesterol-25-hydroxylase promotes efferocytosis and resolution of lung inflammation. JCI Insight 2020, 5. [CrossRef]

72. Jia, J.; Conlon, T.M.; Sarker, R.S.; Taşdemir, D.; Smirnova, N.; Srivastava, B.; Verleden, S.; Güneş, G.; Wu, X.; Prehn, C.; et al. Cholesterol metabolism promotes B-cell positioning during immune pathogenesis of chronic obstructive pulmonary disease. EMBO Mol. Med. 2018, 10, e8349. [CrossRef]

73. Li-Hawkins, J.; Lund, E.G.; Turley, S.D.; Russell, D.W. Disruption of the Oxysterol 7 $\alpha$-Hydroxylase Gene in Mice. J. Biol. Chem. 2000, 275, 16536-16542. [CrossRef]

74. Dulos, J.; Van Der Vleuten, M.A.J.; Kavelaars, A.; Heijnen, C.J.; Boots, A.M. CYP7B expression and activity in fibroblast-like synoviocytes from patients with rheumatoid arthritis: Regulation by proinflammatory cytokines. Arthritis Rheum. 2005, 52, 770-778. [CrossRef] [PubMed]

75. Stoilov, I.; Krueger, W.; Mankowski, D.; Guernsey, L.; Kaur, A.; Glynn, J.; Thrall, R.S. The cytochromes P450 (CYP) response to allergic inflammation of the lung. Arch. Biochem. Biophys. 2006, 456, 30-38. [CrossRef] [PubMed]

76. Raselli, T.; Hearn, T.; Wyss, A.; Atrott, K.; Peter, A.; Frey-Wagner, I.; Spalinger, M.R.; Maggio, E.M.; Sailer, A.W.; Schmitt, J.; et al. Elevated oxysterol levels in human and mouse livers reflect nonalcoholic steatohepatitis. J. Lipid Res. 2019, 60, 1270-1283. [CrossRef]

77. Kakiyama, G.; Marques, D.; Martin, R.; Takei, H.; Rodriguez-Agudo, D.; LaSalle, S.A.; Hashiguchi, T.; Liu, X.; Green, R.; Erickson, S.; et al. Insulin resistance dysregulates CYP7B1 leading to oxysterol accumulation: A pathway for NAFL to NASH transition. J. Lipid Res. 2020, 61, 1629-1644. [CrossRef] [PubMed]

78. Shi, S.-Z.; Lee, E.-J.; Lin, Y.-J.; Chen, L.; Zheng, H.-Y.; He, X.-Q.; Peng, J.-Y.; Noonepalle, S.K.; Shull, A.Y.; Pei, F.C.; et al. Recruitment of monocytes and epigenetic silencing of intratumoral CYP7B1 primarily contribute to the accumulation of 27-hydroxycholesterol in breast cancer. Am. J. Cancer Res. 2019, 9, 2194-2208.

79. Benned-Jensen, T.; Rosenkilde, M.M. Structural Motifs of Importance for the Constitutive Activity of the Orphan 7TM Receptor EBI2: Analysis of Receptor Activation in the Absence of an Agonist. Mol. Pharm. 2008, 74, 1008-1021. [CrossRef]

80. Benned-Jensen, T.; Rosenkilde, M.M. Distinct expression and ligand-binding profiles of two constitutively active GPR17 splice variants. Br. J. Pharm. 2010, 159, 1092-1105. [CrossRef]

81. Zhang, L.; Shih, A.Y.; Yang, X.V.; Kuei, C.; Wu, J.; Deng, X.; Mani, N.S.; Mirzadegan, T.; Sun, S.; Lovenberg, T.W.; et al. Identification of Structural Motifs Critical for Epstein-Barr Virus-Induced Molecule 2 Function and Homology Modeling of the Ligand Docking Site. Mol. Pharm. 2012, 82, 1094-1103. [CrossRef] [PubMed]

82. Benned-Jensen, T.; Norn, C.; Laurent, S.; Madsen, C.M.; Larsen, H.M.; Arfelt, K.N.; Wolf, R.M.; Frimurer, T.; Sailer, A.; Rosenkilde, M.M. Molecular Characterization of Oxysterol Binding to the Epstein-Barr Virus-induced Gene 2 (GPR183). J. Biol. Chem. 2012, 287, 35470-35483. [CrossRef]

83. Sensi, C.; Daniele, S.; Parravicini, C.; Zappelli, E.; Russo, V.; Trincavelli, M.L.; Martini, C.; Abbracchio, M.P.; Eberini, I. Oxysterols act as promiscuous ligands of class-A GPCRs: In silico molecular modeling and in vitro validation. Cell. Signal. 2014, 26, 2614-2620. [CrossRef]

84. Daugvilaite, V.; Madsen, C.M.; Lückmann, M.; Echeverria, C.C.; Sailer, A.W.; Frimurer, T.M.; Rosenkilde, M.M.; Benned-Jensen, T. Biased agonism and allosteric modulation of $\mathrm{G}$ protein-coupled receptor 183-A 7TM receptor also known as Epstein-Barr virus-induced gene 2. Br. J. Pharm. 2017, 174, 2031-2042. [CrossRef]

85. Thal, D.M.; Glukhova, A.; Sexton, P.; Christopoulos, A. Structural insights into G-protein-coupled receptor allostery. Nat. Cell Biol. 2018, 559, 45-53. [CrossRef] [PubMed]

86. Wang, Y.; Yu, Z.; Xiao, W.; Lu, S.; Zhang, J. Allosteric binding sites at the receptor-lipid bilayer interface: Novel targets for GPCR drug discovery. Drug Discov. Today 2020, 26, 690-703. [CrossRef]

87. Guixà-González, R.; Albasanz, J.L.; Rodriguez-Espigares, I.; Pastor, M.; Sanz, F.; Marti-Solano, M.; Manna, M.; Martinez-Seara, H.; Hildebrand, P.W.; Martín, M.; et al. Membrane cholesterol access into a G-protein-coupled receptor. Nat. Commun. $2017,8,14505$. [CrossRef]

88. Coffelt, S.; Kersten, K.; Doornebal, C.W.; Weiden, J.; Vrijland, K.; Hau, C.-S.; Verstegen, N.; Ciampricotti, M.; Hawinkels, L.; Jonkers, J.; et al. IL-17-producing $\gamma \delta \mathrm{T}$ cells and neutrophils conspire to promote breast cancer metastasis. Nat. Cell Biol. 2015, 522, 345-348. [CrossRef]

89. Baek, A.E.; Yu, Y.-R.A.; He, S.; Wardell, S.E.; Chang, C.-Y.; Kwon, S.; Pillai, R.V.; McDowell, H.B.; Thompson, J.W.; Dubois, L.G.; et al. The cholesterol metabolite 27 hydroxycholesterol facilitates breast cancer metastasis through its actions on immune cells. Nat. Commun. 2017, 8, 864. [CrossRef]

90. Addison, C.L.; Daniel, T.O.; Burdick, M.D.; Liu, H.; Ehlert, J.E.; Xue, Y.Y.; Buechi, L.; Walz, A.; Richmond, A.; Strieter, R.M. The CXC Chemokine Receptor 2, CXCR2, Is the Putative Receptor for ELR + CXC Chemokine-Induced Angiogenic Activity. J. Immunol. 2000, 165, 5269-5277. [CrossRef]

91. Khaw, Y.M.; Cunningham, C.; Tierney, A.; Sivaguru, M.; Inoue, M. Neutrophil-selective deletion of Cxcr2 protects against CNS neurodegeneration in a mouse model of multiple sclerosis. J. Neuroinflamm. 2020, 17, 49. [CrossRef] [PubMed]

92. Carlson, T.; Kroenke, M.; Rao, P.; Lane, T.E.; Segal, B. The Th17-ELR + CXC chemokine pathway is essential for the development of central nervous system autoimmune disease. J. Exp. Med. 2008, 205, 811-823. [CrossRef] 
93. Steele, C.W.; A Karim, S.; Foth, M.; Rishi, L.; Leach, J.; Porter, R.; Nixon, C.; Evans, T.J.; Carter, C.R.; Nibbs, R.; et al. CXCR2 inhibition suppresses acute and chronic pancreatic inflammation. J. Pathol. 2015, 237, 85-97. [CrossRef]

94. Farooq, S.M.; Stillie, R.; Svensson, M.; Svanborg, C.; Strieter, R.M.; Stadnyk, A.W. Therapeutic Effect of Blocking CXCR2 on Neutrophil Recruitment and Dextran Sodium Sulfate-Induced Colitis. J. Pharm. Exp. 2009, 329, 123-129. [CrossRef]

95. Zhu, F.; He, H.; Fan, L.; Ma, C.; Xu, Z.; Xue, Y.; Wang, Y.; Zhang, C.; Zhou, G. Blockade of CXCR2 suppresses proinflammatory activities of neutrophils in ulcerative colitis. Am. J. Transl. Res. 2020, 12, 5237-5251. [PubMed]

96. Sinclair, A.; Park, L.; Shah, M.; Drotar, M.; Calaminus, S.; Hopcroft, L.E.M.; Kinstrie, R.; Guitart, A.; Dunn, K.; Abraham, S.; et al. CXCR2 and CXCL4 regulate survival and self-renewal of hematopoietic stem/progenitor cells. Blood 2016, 128, 371-383. [CrossRef]

97. Eash, K.J.; Greenbaum, A.; Gopalan, P.K.; Link, D.C. CXCR2 and CXCR4 antagonistically regulate neutrophil trafficking from murine bone marrow. J. Clin. Investig. 2010, 120, 2423-2431. [CrossRef]

98. Han, X.; Shi, H.; Sun, Y.; Shang, C.; Luan, T.; Wang, D.; Ba, X.; Zeng, X. CXCR2 expression on granulocyte and macrophage progenitors under tumor conditions contributes to mo-MDSC generation via SAP18/ERK/STAT3. Cell Death Dis. 2019, 10, 598 [CrossRef] [PubMed]

99. Ahuja, S.K.; Murphy, P.M. The CXC Chemokines Growth-regulated Oncogene (GRO) $\alpha$, GRO $\beta$, GRO $\gamma$, Neutrophil-activating Peptide-2, and Epithelial Cell-derived Neutrophil-activating Peptide-78 Are Potent Agonists for the Type B, but Not the Type A, Human Interleukin-8 Receptor. J. Biol. Chem. 1996, 271, 20545-20550. [CrossRef] [PubMed]

100. Das, S.T.; Rajagopalan, L.; Guerrero-Plata, A.; Sai, J.; Richmond, A.; Garofalo, R.P.; Rajarathnam, K. Monomeric and Dimeric CXCL8 Are Both Essential for In Vivo Neutrophil Recruitment. PLoS ONE 2010, 5, e11754. [CrossRef] [PubMed]

101. Shaik, S.S.; Soltau, T.D.; Chaturvedi, G.; Totapally, B.; Hagood, J.S.; Andrews, W.W.; Athar, M.; Voitenok, N.N.; Killingsworth, C.R.; Patel, R.; et al. Low Intensity Shear Stress Increases Endothelial ELR + CXC Chemokine Production via a Focal Adhesion Kinasep38ß MAPK-NF-кB Pathway. J. Biol. Chem. 2009, 284, 5945-5955. [CrossRef]

102. Raccosta, L.; Fontana, R.; Traversari, C.; Russo, V. Oxysterols recruit tumor-supporting neutrophils within the tumor microenvironment. OncoImmunology 2013, 2, e26469. [CrossRef]

103. Raccosta, L.; Fontana, R.; Maggioni, D.; Lanterna, C.; Villablanca, E.; Paniccia, A.; Musumeci, A.; Chiricozzi, E.; Trincavelli, M.L.; Daniele, S.; et al. The oxysterol-CXCR2 axis plays a key role in the recruitment of tumor-promoting neutrophils. J. Exp. Med. 2013, 210, 1711-1728. [CrossRef]

104. Liu, K.; Wu, L.; Yuan, S.; Wu, M.; Xu, Y.; Sun, Q.; Li, S.; Zhao, S.; Hua, T.; Liu, Z.-J. Structural basis of CXC chemokine receptor 2 activation and signalling. Nat. Cell Biol. 2020, 585, 135-140. [CrossRef]

105. Catusse, J.; Liotard, A.; Loillier, B.; Pruneau, D.; Paquet, J.-L. Characterization of the molecular interactions of interleukin-8 (CXCL8), growth related oncogen $\alpha$ (CXCL1) and a non-peptide antagonist (SB 225002) with the human CXCR2. Biochem. Pharm. 2003, 65, 813-821. [CrossRef]

106. Nicholls, D.J.; Tomkinson, N.P.; Wiley, K.E.; Brammall, A.; Bowers, L.; Grahames, C.; Gaw, A.; Meghani, P.; Shelton, P.; Wright, T.J.; et al. Identification of a Putative Intracellular Allosteric Antagonist Binding-Site in the CXC Chemokine Receptors 1 and 2. Mol. Pharm. 2008, 74, 1193-1202. [CrossRef]

107. De Kruijf, P.; Van Heteren, J.; Lim, H.D.; Conti, P.G.; Van Der Lee, M.M.C.; Bosch, L.; Ho, K.-K.; Auld, U.; Ohlmeyer, M.; Smit, M.J.; et al. Nonpeptidergic Allosteric Antagonists Differentially Bind to the CXCR2 Chemokine Receptor. J. Pharm. Exp. 2009, 329, 783-790. [CrossRef] [PubMed]

108. Salchow, K.; Bond, M.; Evans, S.; Press, N.; Charlton, S.; Hunt, P.; Bradley, M. A common intracellular allosteric binding site for antagonists of the CXCR2 receptor. Br. J. Pharm. 2010, 159, 1429-1439. [CrossRef]

109. Baugher, P.J.; Richmond, A. The Carboxyl-terminal PDZ Ligand Motif of Chemokine Receptor CXCR2 Modulates Post-endocytic Sorting and Cellular Chemotaxis. J. Biol. Chem. 2008, 283, 30868-30878. [CrossRef] [PubMed]

110. Wu, Y.; Wang, S.; Farooq, S.M.; Castelvetere, M.P.; Hou, Y.; Gao, J.-L.; Navarro, J.; Oupicky, D.; Sun, F.; Li, C. A Chemokine Receptor CXCR2 Macromolecular Complex Regulates Neutrophil Functions in Inflammatory Diseases. J. Biol. Chem. 2012, 287, 5744-5755. [CrossRef]

111. Legler, D.F.; Matti, C.; Laufer, J.M.; Jakobs, B.D.; Purvanov, V.; Allmen, E.U.-V.; Thelen, M. Modulation of Chemokine Receptor Function by Cholesterol: New Prospects for Pharmacological Intervention. Mol. Pharm. 2017, 91, 331-338. [CrossRef]

112. Chen, J.; Taipale, J.; Young, K.E.; Maiti, T.; Beachy, P.A. Small molecule modulation of Smoothened activity. Proc. Natl. Acad. Sci. USA 2002, 99, 14071-14076. [CrossRef]

113. Frank-Kamenetsky, M.; Zhang, X.M.; Bottega, S.; Guicherit, O.; Wichterle, H.; Dudek, H.; Bumcrot, D.; Wang, F.Y.; Jones, S.; Shulok, J.; et al. Small-molecule modulators of Hedgehog signaling: Identification and characterization of Smoothened agonists and antagonists. J. Biol. 2002, 1, 10. [CrossRef]

114. Rohatgi, R.; Milenkovic, L.; Corcoran, R.B.; Scott, M.P. Hedgehog signal transduction by Smoothened: Pharmacologic evidence for a 2-step activation process. Proc. Natl. Acad. Sci. USA 2009, 106, 3196-3201. [CrossRef]

115. Outram, S.V.; Varas, A.; Pepicelli, C.V.; Crompton, T. Hedgehog Signaling Regulates Differentiation from Double-Negative to Double-Positive Thymocyte. Immunity 2000, 13, 187-197. [CrossRef]

116. Shah, D.K.; Hager-Theodorides, A.; Outram, S.V.; Ross, S.E.; Varas, A.; Crompton, T. Reduced Thymocyte Development in Sonic Hedgehog Knockout Embryos. J. Immunol. 2004, 172, 2296-2306. [CrossRef] 
117. Rowbotham, N.J.; Hager-Theodorides, A.L.; Cebecauer, M.; Shah, D.K.; Drakopoulou, E.; Dyson, J.; Outram, S.V.; Crompton, T. Activation of the Hedgehog signaling pathway in T-lineage cells inhibits TCR repertoire selection in the thymus and peripheral T-cell activation. Blood 2007, 109, 3757-3766. [CrossRef] [PubMed]

118. Rowbotham, N.J.; Furmanski, A.L.; Hager-Theodorides, A.L.; Ross, S.E.; Drakopoulou, E.; Koufaris, C.; Outram, S.V.; Crompton, T. Repression of Hedgehog signal transduction in T-lineage cells increases TCR-induced activation and proliferation. Cell Cycle 2008, 7, 904-908. [CrossRef] [PubMed]

119. Mengrelis, K.; Lau, C.-I.; Rowell, J.; Solanki, A.; Norris, S.; Ross, S.; Ono, M.; Outram, S.; Crompton, T. Sonic Hedgehog Is a Determinant of $\gamma \delta$ T-Cell Differentiation in the Thymus. Front. Immunol. 2019, 10, 1629. [CrossRef] [PubMed]

120. Saldana, J.I.; Solanki, A.; Lau, C.-I.; Sahni, H.; Ross, S.; Furmanski, A.L.; Ono, M.; Holländer, G.; Crompton, T. Sonic Hedgehog regulates thymic epithelial cell differentiation. J. Autoimmun. 2016, 68, 86-97. [CrossRef]

121. Furmanski, A.L.; Saldana, J.I.; Ono, M.; Sahni, H.; Paschalidis, N.; D'Acquisto, F.; Crompton, T. Tissue-Derived Hedgehog Proteins Modulate Th Differentiation and Disease. J. Immunol. 2013, 190, 2641-2649. [CrossRef]

122. de la Roche, M.; Ritter, A.T.; Angus, K.L.; Dinsmore, C.; Earnshaw, C.H.; Reiter, J.F.; Griffiths, G.M. Hedgehog Signaling Controls T Cell Killing at the Immunological Synapse. Science 2013, 342, 1247-1250. [CrossRef]

123. Syn, W.-K.; Witek, R.P.; Curbishley, S.M.; Jung, Y.; Choi, S.S.; Enrich, B.; Omenetti, A.; Agboola, K.M.; Fearing, C.M.; Tilg, H.; et al. Role for hedgehog pathway in regulating growth and function of invariant NKT cells. Eur. J. Immunol. 2009, 39, 1879-1892. [CrossRef]

124. Solanki, A.; Lau, C.I.; Saldaña, J.I.; Ross, S.; Crompton, T. The transcription factor Gli3 promotes B cell development in fetal liver through repression of Shh. J. Exp. Med. 2017, 214, 2041-2058. [CrossRef]

125. Solanki, A.; Yanez, D.C.; Ross, S.; Lau, C.I.; Papaioannou, E.; Li, J.; Saldaña, J.I.; Crompton, T. In the fetal thymus, Gli3 in thymic epithelial cells promotes thymocyte positive selection and differentiation by repression of Shh. Development 2018, 145. [CrossRef]

126. Papaioannou, E.; Yánez, D.C.; Ross, S.; Lau, C.-I.; Solanki, A.; Chawda, M.M.; Virasami, A.; Ranz, I.; Ono, M.; O'Shaughnessy, R.F.L.; et al. Sonic Hedgehog signaling limits atopic dermatitis via Gli2-driven immune regulation. J. Clin. Investig. 2019, 129, 3153-3170. [CrossRef] [PubMed]

127. Myers, B.R.; Sever, N.; Chong, Y.C.; Kim, J.; Belani, J.D.; Rychnovsky, S.; Bazan, J.F.; Beachy, P.A. Hedgehog Pathway Modulation by Multiple Lipid Binding Sites on the Smoothened Effector of Signal Response. Dev. Cell 2013, 26, 346-357. [CrossRef] [PubMed]

128. Cooper, M.K.; Wassif, C.; Krakowiak, P.A.; Taipale, J.; Gong, R.; Kelley, R.I.; Porter, F.D.; Beachy, P.A. A defective response to Hedgehog signaling in disorders of cholesterol biosynthesis. Nat. Genet. 2003, 33, 508-513. [CrossRef] [PubMed]

129. Xiao, X.; Tang, J.-J.; Peng, C.; Wang, Y.; Fu, L.; Qiu, Z.-P.; Xiong, Y.; Yang, L.-F.; Cui, H.-W.; He, X.-L.; et al. Cholesterol Modification of Smoothened Is Required for Hedgehog Signaling. Mol. Cell 2017, 66, 154-162.e10. [CrossRef]

130. Raleigh, D.R.; Sever, N.; Choksi, P.K.; Sigg, M.; Hines, K.; Thompson, B.; Elnatan, D.; Jaishankar, P.; Bisignano, P.; Garcia-Gonzalo, F.; et al. Cilia-Associated Oxysterols Activate Smoothened. Mol. Cell 2018, 72, 316-327.e5. [CrossRef]

131. Huang, P.; Nedelcu, D.; Watanabe, M.; Jao, C.; Kim, Y.; Liu, J.; Salic, A. Cellular Cholesterol Directly Activates Smoothened in Hedgehog Signaling. Cell 2016, 166, 1176-1187. [CrossRef]

132. Zhang, X.; Zhao, F.; Wu, Y.; Yang, J.; Han, G.W.; Zhao, S.; Ishchenko, A.; Ye, L.; Lin, X.; Ding, K.; et al. Crystal structure of a multi-domain human smoothened receptor in complex with a super stabilizing ligand. Nat. Commun. 2017, 8, 15383. [CrossRef]

133. Huang, P.; Zheng, S.; Wierbowski, B.; Kim, Y.; Nedelcu, D.; Aravena, L.; Liu, J.; Kruse, A.C.; Salic, A. Structural Basis of Smoothened Activation in Hedgehog Signaling. Cell 2018, 174, 312-324. [CrossRef] [PubMed]

134. Deshpande, I.; Liang, J.; Hedeen, D.; Roberts, K.J.; Zhang, Y.; Ha, B.; Latorraca, N.R.; Faust, B.; Dror, R.O.; Beachy, P.A.; et al. Smoothened stimulation by membrane sterols drives Hedgehog pathway activity. Nat. Cell Biol. 2019, 571, 284-288. [CrossRef]

135. Qi, X.; Friedberg, L.; De Bose-Boyd, R.; Long, T.; Li, X. Sterols in an intramolecular channel of Smoothened mediate Hedgehog signaling. Nat. Chem. Biol. 2020, 16, 1368-1375. [CrossRef] [PubMed]

136. Phelan, K.; Mahler, H. Acute Exposure to 25-Hydroxy-cholesterol Selectively Reduces GABAb and Not GABAa Receptor-Mediated Synaptic Inhibition. Biochem. Biophys. Res. Commun. 1997, 237, 68-73. [CrossRef]

137. A Kuhn, S.; van Landeghem, F.; Zacharias, R.; Färber, K.; Rappert, A.; Pavlovic, S.; Hoffmann, A.; Nolte, C.; Kettenmann, H. Microglia express GABAB receptors to modulate interleukin release. Mol. Cell. Neurosci. 2004, 25, 312-322. [CrossRef]

138. Huang, S.; Mao, J.; Wei, B.; Pei, G. The anti-spasticity drug baclofen alleviates collagen-induced arthritis and regulates dendritic cells. J. Cell. Physiol. 2015, 230, 1438-1447. [CrossRef] [PubMed]

139. Hammoud, Y.; Rice, T.; Mackrill, J.J. Oxysterols modulate calcium signalling in the A7r5 aortic smooth muscle cell-line. Biochimie 2013, 95, 568-577. [CrossRef]

140. Yan, Z.; Li, S.; Liang, Z.; Tomić, M.; Stojilkovic, S.S. The P2X7 Receptor Channel Pore Dilates under Physiological Ion Conditions. J. Gen. Physiol. 2008, 132, 563-573. [CrossRef]

141. McCarthy, A.E.; Yoshioka, C.; Mansoor, S.E. Full-Length P2X7 Structures Reveal How Palmitoylation Prevents Channel Desensitization. Cell 2019, 179, 659-670. [CrossRef]

142. Robinson, L.E.; Shridar, M.; Smith, P.; Murrell-Lagnado, R.D. Plasma Membrane Cholesterol as a Regulator of Human and Rodent P2X7 Receptor Activation and Sensitization. J. Biol. Chem. 2014, 289, 31983-31994. [CrossRef]

143. Lajdova, I.; Chorvát, D.; Chorvatova, A. Rapid effects of $1 \alpha, 25(\mathrm{OH}) 2 \mathrm{D} 3$ in resting human peripheral blood mononuclear cells. Eur. J. Pharm. 2008, 586, 14-23. [CrossRef] [PubMed] 
144. Olivier, E.; Dutot, M.; Regazzetti, A.; Laprévote, O.; Rat, P. 25-Hydroxycholesterol induces both P2X7-dependent pyroptosis and caspase-dependent apoptosis in human skin model: New insights into degenerative pathways. Chem. Phys. Lipids 2017, 207, 171-178. [CrossRef] [PubMed]

145. Adinolfi, E.; Giuliani, A.L.; De Marchi, E.; Pegoraro, A.; Orioli, E.; Di Virgilio, F. The P2X7 receptor: A main player in inflammation. Biochem. Pharm. 2018, 151, 234-244. [CrossRef]

146. Olivier, E.; Dutot, M.; Regazzetti, A.; Leguillier, T.; Dargère, D.; Auzeil, N.; Laprévote, O.; Rat, P. P2X7-pannexin-1 and amyloid $\beta$-induced oxysterol input in human retinal cell: Role in age-related macular degeneration? Biochimie 2016, 127, 70-78. [CrossRef] [PubMed]

147. A Grahames, C.B.; Michel, A.D.; Chessell, I.P.; A Humphrey, P.P. Pharmacological characterization of ATP- and LPS-induced IL-1 $\beta$ release in human monocytes. Br. J. Pharm. 1999, 127, 1915-1921. [CrossRef]

148. Martinez-García, J.J.; Banaclocha, H.M.; Angosto, D.; De Torre-Minguela, C.; Baroja-Mazo, A.; Alarcón-Vila, C.; Martinez-Alarcon, L.; Amores-Iniesta, J.; Martín-Sánchez, F.; Ercole, G.A.; et al. P2X7 receptor induces mitochondrial failure in monocytes and compromises NLRP3 inflammasome activation during sepsis. Nat. Commun. 2019, 10, 2711. [CrossRef]

149. Grassi, F. The P2X7 Receptor as Regulator of T Cell Development and Function. Front. Immunol. 2020, 11, 1179. [CrossRef] [PubMed]

150. Tsukimoto, M.; Tokunaga, A.; Harada, H.; Kojima, S. Blockade of murine T cell activation by antagonists of P2Y6 and P2X7 receptors. Biochem. Biophys. Res. Commun. 2009, 384, 512-518. [CrossRef]

151. Schenk, U.; Frascoli, M.; Proietti, M.; Geffers, R.; Traggiai, E.; Buer, J.; Ricordi, C.; Westendorf, A.M.; Grassi, F. ATP Inhibits the Generation and Function of Regulatory T Cells Through the Activation of Purinergic P2X Receptors. Sci. Signal. 2011, 4, ra12. [CrossRef]

152. Frascoli, M.; Marcandalli, J.; Schenk, U.; Grassi, F. Purinergic P2X7 Receptor Drives T Cell Lineage Choice and Shapes Peripheral $\gamma \delta$ Cells. J. Immunol. 2012, 189, 174-180. [CrossRef] [PubMed]

153. Beynon, V.; Quintana, F.J.; Weiner, H.L. Activated Human $\mathrm{CD}^{4+} \mathrm{CD}^{45} \mathrm{RO}^{+}$Memory T-Cells Indirectly Inhibit NLRP3 Inflammasome Activation through Downregulation of P2X7R Signalling. PLoS ONE 2012, 7, e39576. [CrossRef] [PubMed]

154. De Salles, M.; Menezes, M.; Siqueira, R.; Da Silva, H.B.; Amaral, E.P.; Castillo-Méndez, S.I.; Cunha, I.; Cassado, A.D.A.; Vieira, F.S.; Olivieri, D.N.; et al. P2X7 receptor drives Th1 cell differentiation and controls the follicular helper T cell population to protect against Plasmodium chabaudi malaria. Plos Pathog. 2017, 13, e1006595. [CrossRef]

155. Da Silva, H.B.; Beura, L.K.; Wang, H.; Hanse, E.A.; Gore, R.; Scott, M.C.; Walsh, D.A.; Block, K.E.; Fonseca, R.; Yan, Y.; et al. The purinergic receptor P2RX7 directs metabolic fitness of long-lived memory CD $^{8+}$ T cells. Nat. Cell Biol. 2018, 559, 264-268. [CrossRef]

156. Dubyak, G.R. P2X7 receptor regulation of non-classical secretion from immune effector cells. Cell. Microbiol. 2012, 14, 1697-1706. [CrossRef]

157. Baroja-Mazo, A.; Barberà-Cremades, M.; Pelegrín, P. P2X7 Receptor Activation Impairs Exogenous MHC Class I Oligopeptides Presentation in Antigen Presenting Cells. PLoS ONE 2013, 8, e70577. [CrossRef]

158. Figliuolo, V.R.; Savio, L.E.; Safya, H.; Nanini, H.F.; Bernardazzi, C.; Abalo, A.; de Souza, H.S.; Kanellopoulos, J.; Bobé, P.; Coutinho, C.M.; et al. P2X7 receptor promotes intestinal inflammation in chemically induced colitis and triggers death of mucosal regulatory T cells. Mol. Basis Dis. 2017, 1863, 1183-1194. [CrossRef]

159. Salussolia, C.L.; Prodromou, M.L.; Borker, P.; Wollmuth, L.P. Arrangement of Subunits in Functional NMDA Receptors. J. Neurosci. 2011, 31, 11295-11304. [CrossRef]

160. Zhu, S.; Gouaux, E. Structure and symmetry inform gating principles of ionotropic glutamate receptors. Neuropharmacology 2016, 112, 11-15. [CrossRef]

161. Pérez-Otaño, I.; Larsen, R.; Wesseling, I.P.-O.J.F. Emerging roles of GluN3-containing NMDA receptors in the CNS. Nat. Rev. Neurosci. 2016, 17, 623-635. [CrossRef] [PubMed]

162. Hogan-Cann, A.D.; Anderson, C.M. Physiological Roles of Non-Neuronal NMDA Receptors. Trends Pharm. Sci. 2016, 37, 750-767. [CrossRef]

163. Ganor, Y.; Levite, M. The neurotransmitter glutamate and human T cells: Glutamate receptors and glutamate-induced direct and potent effects on normal human T cells, cancerous human leukemia and lymphoma T cells, and autoimmune human T cells. J. Neural Transm. 2014, 121, 983-1006. [CrossRef] [PubMed]

164. Paul, S.M.; Doherty, J.J.; Robichaud, A.J.; Belfort, G.M.; Chow, B.Y.; Hammond, R.S.; Crawford, D.; Linsenbardt, A.J.; Shu, H.-J.; Izumi, Y.; et al. The Major Brain Cholesterol Metabolite 24(S)-Hydroxycholesterol Is a Potent Allosteric Modulator of N-Methyl-DAspartate Receptors. J. Neurosci. 2013, 33, 17290-17300. [CrossRef] [PubMed]

165. Emnett, C.M.; Eisenman, L.N.; Mohan, J.; A Taylor, A.; Doherty, J.J.; Paul, S.M.; Zorumski, C.F.; Mennerick, S. Interaction between positive allosteric modulators and trapping blockers of the NMDA receptor channel. Br. J. Pharm. 2015, 172, 1333-1347. [CrossRef]

166. Sun, M.-Y.; Izumi, Y.; Benz, A.M.; Zorumski, C.F.; Mennerick, S. Endogenous 24S-hydroxycholesterol modulates NMDARmediated function in hippocampal slices. J. Neurophysiol. 2016, 115, 1263-1272. [CrossRef] [PubMed]

167. Wilding, T.J.; Lopez, M.N.; Huettner, J.E. Chimeric Glutamate Receptor Subunits Reveal the Transmembrane Domain Is Sufficient for NMDA Receptor Pore Properties but Some Positive Allosteric Modulators Require Additional Domains. J. Neurosci. 2016, 36, 8815-8825. [CrossRef] 
168. Wei, X.; Nishi, T.; Kondou, S.; Kimura, H.; Mody, I. Preferential enhancement of GluN2B-containing native NMDA receptors by the endogenous modulator 24S-hydroxycholesterol in hippocampal neurons. Neuropharmacology 2018, 148, 11-20. [CrossRef]

169. Sun, M.-Y.; Taylor, A.; Zorumski, C.F.; Mennerick, S. 24S-hydroxycholesterol and 25-hydroxycholesterol differentially impact hippocampal neuronal survival following oxygen-glucose deprivation. PLoS ONE 2017, 12, e0174416. [CrossRef]

170. Mateos, L.; Akterin, S.; Gil-Bea, F.; Spulber, S.; Rahman, A.; Björkhem, I.; Schultzberg, M.; Flores-Morales, A.; Cedazo-Mínguez, A. Activity-Regulated Cytoskeleton-Associated Protein in Rodent Brain is Down-Regulated by High Fat Dietin vivoand by 27Hydroxycholesterolin vitro. Brain Pathol. 2008, 19, 69-80. [CrossRef]

171. Boldyrev, A.A.; Carpenter, D.O.; Johnson, P. Emerging evidence for a similar role of glutamate receptors in the nervous and immune systems. J. Neurochem. 2005, 95, 913-918. [CrossRef] [PubMed]

172. Mashkina, A.P.; Tyulina, O.V.; Solovyova, T.I.; Kovalenko, E.; Kanevski, L.M.; Johnson, P.; Boldyrev, A.A. The excitotoxic effect of NMDA on human lymphocyte immune function. Neurochem. Int. 2007, 51, 356-360. [CrossRef]

173. Kahlfuß, S.; Simma, N.; Mankiewicz, J.; Bose, T.; Lowinus, T.; Klein-Hessling, S.; Sprengel, R.; Schraven, B.; Heine, M.; Bommhardt, U. Immunosuppression by N-Methyl-D-Aspartate Receptor Antagonists Is Mediated through Inhibition of Kv1.3 and KCa3.1 Channels in T Cells. Mol. Cell. Biol. 2013, 34, 820-831. [CrossRef]

174. Simma, N.; Bose, T.; Kahlfuß, S.; Mankiewicz, J.; Lowinus, T.; Lühder, F.; Schüler, T.; Schraven, B.; Heine, M.; Bommhardt, U. NMDA-receptor antagonists block B-cell function but foster IL-10 production in BCR/CD40-activated B cells. Cell Commun. Signal. 2014, 12, 75. [CrossRef] [PubMed]

175. Miller, P.S.; Aricescu, A.R. Crystal structure of a human GABAA receptor. Nat. Cell Biol. 2014, 512, 270-275. [CrossRef]

176. Alvarez, L.D.; Pecci, A.; Estrin, D.A. In Search of GABAA Receptor's Neurosteroid Binding Sites. J. Med. Chem. 2018, 62, 5250-5260. [CrossRef] [PubMed]

177. Barragan, A.; Weidner, J.M.; Jin, Z.; Korpi, E.R.; Birnir, B. GABAergic signalling in the immune system. Acta Physiol. 2015, 213, 819-827. [CrossRef]

178. Rudy, B.; McBain, C.J. Kv3 channels: Voltage-gated K+ channels designed for high-frequency repetitive firing. Trends Neurosci. 2001, 24, 517-526. [CrossRef]

179. Bezine, M.; Maatoug, S.; Ben Khalifa, R.; Debbabi, M.; Zarrouk, A.; Wang, Y.; Griffiths, W.J.; Nury, T.; Samadi, M.; Vejux, A.; et al. Modulation of Kv3.1b potassium channel level and intracellular potassium concentration in $158 \mathrm{~N}$ murine oligodendrocytes and BV-2 murine microglial cells treated with 7-ketocholesterol, 24S-hydroxycholesterol or tetracosanoic acid (C24:0). Biochimie 2018, 153, 56-69. [CrossRef]

180. Grissmer, S.; Ghanshani, S.; Dethlefs, B.; McPherson, J.D.; Wasmuth, J.J.; Gutman, G.A.; Cahalan, M.D.; Chandy, K.G. The Shaw-related potassium channel gene, Kv3.1, on human chromosome 11, encodes the type $1 \mathrm{~K}+$ channel in T cells. J. Biol. Chem. 1992, 267, 20971-20979. [CrossRef]

181. Black, J.A.; Waxman, S.G. Noncanonical Roles of Voltage-Gated Sodium Channels. Neuron 2013, 80, 280-291. [CrossRef] [PubMed]

182. Roselli, F.; Livrea, P.; Jirillo, E. Voltage-Gated Sodium Channel Blockers as Immunomodulators. Recent Pat. CNS Drug Discov. 2006, 1, 83-91. [CrossRef]

183. Bezine, M.; Namsi, A.; Sghaier, R.; Ben Khalifa, R.; Hamdouni, H.; Brahmi, F.; Badreddine, I.; Mihoubi, W.; Nury, T.; Vejux, A.; et al. The effect of oxysterols on nerve impulses. Biochimie 2018, 153, 46-51. [CrossRef]

184. Pristerà, A.; Baker, M.D.; Okuse, K. Association between Tetrodotoxin Resistant Channels and Lipid Rafts Regulates Sensory Neuron Excitability. PLoS ONE 2012, 7, e40079. [CrossRef] [PubMed]

185. Tang, L.; Wang, Y.; Leng, T.; Sun, H.; Zhou, Y.; Zhu, W.; Qiu, P.; Zhang, J.; Lu, B.; Yan, M.; et al. Cholesterol metabolite cholestane-3 $\beta, 5 \alpha, 6 \beta$-triol suppresses epileptic seizures by negative modulation of voltage-gated sodium channels. Steroids 2015, 98, 166-172. [CrossRef] [PubMed]

186. Tang, L.; Yan, M.; Leng, T.; Yin, W.; Cai, S.; Duan, S.; Zhu, W.; Lin, S.; Huang, J.; Yan, G.; et al. Cholestane-3 $\beta, 5 \alpha, 6 \beta$-triol suppresses neuronal hyperexcitability via binding to voltage-gated sodium channels. Biochem. Biophys. Res. Commun. 2018, 496, 95-100. [CrossRef] [PubMed]

187. Mandler, R.N.; Seamer, L.C.; Whitlinger, D.; Lennon, M.; Rosenberg, E.; Bankhurst, A.D. Human natural killer cells express Na+ channels. A pharmacologic flow cytometric study. J. Immunol. 1990, 144, 2365-2370.

188. Lai, Z.-F.; Chen, Y.-Z.; Nishimura, Y.; Nishi, K. An amiloride-sensitive and voltage-dependent Na+ channel in an HLA-DRrestricted human T cell clone. J. Immunol. 2000, 165, 83-90. [CrossRef]

189. Huang, W.; Lu, C.; Wu, Y.; Ouyang, S.; Chen, Y. Identification and functional characterization of voltage-gated sodium channels in lymphocytes. Biochem. Biophys. Res. Commun. 2015, 458, 294-299. [CrossRef] [PubMed]

190. Milam, A.A.V.; Bartleson, J.M.; Donermeyer, D.L.; Horvath, S.; Durai, V.; Raju, S.; Yu, H.; Redmann, V.; Zinselmeyer, B.; White, J.M.; et al. Tuning T Cell Signaling Sensitivity Alters the Behavior of CD4+ T Cells during an Immune Response. J. Immunol. 2018, 200, 3429-3437. [CrossRef]

191. Zsiros, E.; Kis-Toth, K.; Hajdu, P.; Gaspar, R.; Bielanska, J.; Felipe, A.; Rajnavolgyi, E.; Panyi, G. Developmental Switch of the Expression of Ion Channels in Human Dendritic Cells. J. Immunol. 2009, 183, 4483-4492. [CrossRef]

192. Black, J.A.; Waxman, S.G. Sodium channels and microglial function. Exp. Neurol. 2011, 234, 302-315. [CrossRef] [PubMed]

193. Carrithers, M.D.; Dib-Hajj, S.; Carrithers, L.M.; Tokmoulina, G.; Pypaert, M.; Jonas, E.A.; Waxman, S.G. Expression of the Voltage-Gated Sodium Channel NaV1.5 in the Macrophage Late Endosome Regulates Endosomal Acidification. J. Immunol. 2007, 178, 7822-7832. [CrossRef] 
194. Carrithers, L.M.; Hulseberg, P.; Sandor, M.; Carrithers, M.D. The human macrophage sodium channel NaV1.5 regulates mycobacteria processing through organelle polarization and localized calcium oscillations. FEMS Immunol. Med. Microbiol. 2011, 63, 319-327. [CrossRef]

195. Jones, A.; Kainz, D.; Khan, F.; Lee, C.; Carrithers, M.D. Human Macrophage SCN5A Activates an Innate Immune Signaling Pathway for Antiviral Host Defense. J. Biol. Chem. 2014, 289, 35326-35340. [CrossRef]

196. White, C.R.; Dungan, M.; Carrithers, M.D. Activation of human macrophage sodium channels regulates RNA processing to increase expression of the DNA repair protein PPP1R10. Immunobiology 2018, 224, 80-93. [CrossRef]

197. Sun, H.; Jiang, J.; Gong, L.; Li, X.; Yang, Y.; Luo, Y.; Guo, Z.; Lu, R.; Li, H.; Li, J.; et al. Voltage-gated sodium channel inhibitor reduces atherosclerosis by modulating monocyte/macrophage subsets and suppressing macrophage proliferation. Biomed. Pharm. 2019, 120, 109352. [CrossRef]

198. Gonzalez-Perez, V.; Lingle, C.J. Regulation of BK Channels by Beta and Gamma Subunits. Annu. Rev. Physiol. 2019, 81, 113-137. [CrossRef]

199. Tian, Y.; Heinemann, S.H.; Hoshi, T. Large-conductance $\mathrm{Ca}^{2+}$ - and voltage-gated $\mathrm{K}+$ channels form and break interactions with membrane lipids during each gating cycle. Proc. Natl. Acad. Sci. USA 2019, 116, 8591-8596. [CrossRef]

200. Dopico, A.M.; Bukiya, A.N. Regulation of $\mathrm{Ca}^{2+}$-Sensitive $\mathrm{K}+$ Channels by Cholesterol and Bile Acids via Distinct Channel Subunits and Sites. Curr. Top. Membr. 2017, 80, 53-93. [CrossRef] [PubMed]

201. Tajima, N.; Xiaoyan, L.; Taniguchi, M.; Kato, N. 24S-hydroxycholesterol alters activity of large-conductance Ca ${ }^{2+}$-dependent K+ (slo1 BK) channel through intercalation into plasma membrane. Mol. Cell Biol. Lipids 2019, 1864, 1525-1535. [CrossRef]

202. Son, Y.; Chun, W.; Ahn, Y.-T.; Kim, K.; Lee, C.-W.; Kim, J.-M.; Lee, C.; An, W.G. 7-Ketocholesterol induces the reduction of KCNMB1 in atherosclerotic blood vessels. Biochem. Biophys. Res. Commun. 2015, 457, 324-327. [CrossRef]

203. Erdogan, A.; Schaefer, M.B.; Kuhlmann, C.R.W.; Most, A.; Hartmann, M.; Mayer, K.; Renner, F.C.; Schaefer, C.; Abdallah, Y.; Hoelschermann, $\mathrm{H}$; ; et al. Activation of $\mathrm{Ca}^{2+}$-activated potassium channels is involved in lysophosphatidylcholine-induced monocyte adhesion to endothelial cells. Atherosclerosis 2007, 190, 100-105. [CrossRef] [PubMed]

204. Papavlassopoulos, M.; Stamme, C.; Thon, L.; Adam, D.; Hillemann, D.; Seydel, U.; Schromm, A.B. MaxiK Blockade Selectively Inhibits the Lipopolysaccharide-Induced IкB- $\alpha$ /NF-кB Signaling Pathway in Macrophages. J. Immunol. 2006, 177, $4086-4093$. [CrossRef] [PubMed]

205. Sun, X.; Xu, M.; Cao, Q.; Huang, P.; Zhu, X.; Dong, X.-P. A lysosomal $\mathrm{K}^{+}$channel regulates large particle phagocytosis by facilitating lysosome $\mathrm{Ca}^{2+}$ release. Sci. Rep. 2020, 10, 1038. [CrossRef] [PubMed]

206. Selezneva, A.; Yoshida, M.; Gibb, A.; Willis, D. Nuclear BK channels regulate CREB phosphorylation in RAW264.7 macrophages. Pharm. Rep. 2021, 73, 881-890. [CrossRef]

207. Chen, X.; Sooch, G.; Demaree, I.; White, F.; Obukhov, A. Transient Receptor Potential Canonical (TRPC) Channels: Then and Now. Cells 2020, 9, 1983. [CrossRef]

208. Berthier, A.; Lemaire-Ewing, S.; Prunet, C.; Monier, S.; Athias, A.; Bessède, G.; De Barros, J.-P.P.; Laubriet, A.; Gambert, P.; Lizard, G.; et al. Involvement of a calcium-dependent dephosphorylation of BAD associated with the localization of Trpc-1 within lipid rafts in 7-ketocholesterol-induced THP-1 cell apoptosis. Cell Death Differ. 2004, 11, 897-905. [CrossRef]

209. Ingueneau, C.; Huynh-Do, U.; Marcheix, B.; Athias, A.; Gambert, P.; Nègre-Salvayre, A.; Salvayre, R.; Vindis, C. TRPC1 is regulated by caveolin-1 and is involved in oxidized LDL-induced apoptosis of vascular smooth muscle cells. J. Cell. Mol. Med. 2008, 13, 1620-1631. [CrossRef]

210. Wenning, A.S.; Neblung, K.; Strauß, B.; Wolfs, M.-J.; Sappok, A.; Hoth, M.; Schwarz, E.C. TRP expression pattern and the functional importance of TRPC3 in primary human T-cells. Mol. Cell Res. 2011, 1813, 412-423. [CrossRef]

211. Lindemann, O.; Strodthoff, C.; Horstmann, M.; Nielsen, N.; Jung, F.; Schimmelpfennig, S.; Heitzmann, M.; Schwab, A. TRPC1 regulates fMLP-stimulated migration and chemotaxis of neutrophil granulocytes. Mol. Cell Res. 2015, 1853, 2122-2130. [CrossRef] [PubMed]

212. Chauhan, A.; Sun, Y.; Sukumaran, P.; Zangbede, F.O.Q.; Jondle, C.N.; Sharma, A.; Evans, D.L.; Chauhan, P.; Szlabick, R.E.; Aaland, M.O.; et al. M1 Macrophage Polarization Is Dependent on TRPC1-Mediated Calcium Entry. iScience 2018, 8, 85-102. [CrossRef] [PubMed]

213. Da Conceicao, V.N.; Sun, Y.; Zboril, E.K.; De la Chapa, J.J.; Singh, B.B. Loss of Ca ${ }^{2+}$ entry via Orai-TRPC1 induces ER stress that initiates immune activation in macrophage cells. J. Cell Sci. 2019, 133. [CrossRef]

214. Sun, Y.; Chauhan, A.; Sukumaran, P.; Sharma, J.; Singh, B.B.; Mishra, B.B. Inhibition of store-operated calcium entry in microglia by helminth factors: Implications for immune suppression in neurocysticercosis. J. Neuroinflamm. 2014, 11, 210. [CrossRef] [PubMed] 